Article

\title{
Coping with Environmental Eukaryotes; Identification of Pseudomonas syringae Genes during the Interaction with Alternative Hosts or Predators
}

\author{
Federico Dorati ${ }^{1}$, Glyn A. Barrett ${ }^{1, *(1)}$, Maria Sanchez-Contreras ${ }^{2}$, Tanya Arseneault ${ }^{1,3}$, \\ Mateo San José ${ }^{1}$, David J. Studholme ${ }^{4}$ iD, Jesús Murillo ${ }^{5}$, Primitivo Caballero ${ }^{5}$, \\ Nicholas R. Waterfield ${ }^{2,6}$, Dawn L. Arnold ${ }^{7}$, Liz J. Shaw ${ }^{8}$ and Robert W. Jackson ${ }^{1}$ \\ 1 School of Biological Sciences, University of Reading, Reading RG6 6UR, UK; f.dorati83@gmail.com (F.D.); \\ tanya.arseneault@canada.ca (T.A.); matsjg@gmail.com (M.S.J.); r.w.jackson@reading.ac.uk (R.W.J.) \\ 2 Department of Biology and Biochemistry, University of Bath, Bath BA1 9BJ, UK; \\ mariasancon@gmail.com (M.S.-C.); n.r.waterfield@warwick.ac.uk (N.R.W.) \\ 3 Research and Development Centre, Agriculture and Agri-Food Canada, Saint-Jean-sur-Richelieu, \\ QC J3B 3E6, Canada \\ 4 School of Biosciences, University of Exeter, Exeter EX4 4QD, UK; d.j.studholme@exeter.ac.uk \\ 5 Instituto de Agrobiotecnología, Universidad Pública de Navarra, 31192 Mutilva, Spain; \\ jesus.murillo@unavarra.es (J.M.); pcm92@unavarra.es (P.C.) \\ 6 Warwick Medical School, University of Warwick, Warwick CV4 7AL, UK \\ 7 Centre for Research in Bioscience, Faculty of Health and Applied Sciences, University of the West of \\ England, Bristol BS16 1QY, UK; dawn.arnold@uwe.ac.uk \\ 8 School of Archaeology, Geography and Environmental Science, University of Reading, Reading RG6 6AX, \\ UK; e.j.shaw@reading.ac.uk \\ * Correspondence: glyn.barrett@reading.ac.uk; Tel.: +44-118-378-8893
}

Received: 20 March 2018; Accepted: 20 April 2018; Published: 21 April 2018

Abstract: Understanding the molecular mechanisms underpinning the ecological success of plant pathogens is critical to develop strategies for controlling diseases and protecting crops. Recent observations have shown that plant pathogenic bacteria, particularly Pseudomonas, exist in a range of natural environments away from their natural plant host e.g., water courses, soil, non-host plants. This exposes them to a variety of eukaryotic predators such as nematodes, insects and amoebae present in the environment. Nematodes and amoeba in particular are bacterial predators while insect herbivores may act as indirect predators, ingesting bacteria on plant tissue. We therefore postulated that bacteria are probably under selective pressure to avoid or survive predation and have therefore developed appropriate coping mechanisms. We tested the hypothesis that plant pathogenic Pseudomonas syringae are able to cope with predation pressure and found that three pathovars show weak, but significant resistance or toxicity. To identify the gene systems that contribute to resistance or toxicity we applied a heterologous screening technique, called Rapid Virulence Annotation (RVA), for anti-predation and toxicity mechanisms. Three cosmid libraries for P. syringae pv. aesculi, pv. tomato and pv. phaseolicola, of approximately 2000 cosmids each, were screened in the susceptible/non-toxic bacterium Escherichia coli against nematode, amoebae and an insect. A number of potential conserved and unique genes were identified which included genes encoding haemolysins, biofilm formation, motility and adhesion. These data provide the first multi-pathovar comparative insight to how plant pathogens cope with different predation pressures and infection of an insect gut and provide a foundation for further study into the function of selected genes and their role in ecological success.

Keywords: Pseudomonas syringae; rapid virulence annotation; RVA; pathogen; anti-predation; Caenorhabditis elegans; Acanthamoeba polyphaga; Galleria mellonella 


\section{Introduction}

A major challenge in securing global food security is to reduce the impact of disease in food and resource plants (e.g., trees), and to prevent the emergence of new pathogens. Much of the seminal work in the understanding of plant resistance has relied upon a foundation of knowledge of the role and functionality of pathogen systems (e.g., type III protein secretion). However, a poorly understood branch of pathogen biology is their wider ecological success and epidemiology. How does a pathogen survive ex planta after an infected plant dies and deposits its tissue, with high titers of pathogen, into soil or water?

Recent work by Morris and colleagues has discovered that plant pathogens can be isolated from a wide range of environments, can be highly dispersed and are often genetically distinct [1,2]. For example, Pseudomonas syringae can be found from clouds to snow pack and river courses $[3,4]$. This highlights a major gap in our knowledge, particularly when considering functional studies-how do the pathogens survive when not in their host plant? This question can be addressed at many levels, for example, are there different plant hosts, animal hosts, or abilities to tolerate vastly different chemical environments? Thus, an understanding of the ecology of plant pathogens and discovering the mechanisms underpinning bacterial survival in the environment is critical both for increasing knowledge in bacterial evolution and to prevent or control dispersal.

The plant-pathogenic bacterium Pseudomonas syringae is regarded as the most important model pathogen for use in the study of bacterial plant disease [5]. It has recently been the central focus for studying plant pathogen ecology outside of its "host" plant, having been discovered in a range of different habitats often independent from the sphere of agricultural production influence [6]. P. syringae can be transmitted into the atmosphere through the evapotranspiration of water from plants and reach the clouds at several kilometers in altitude [7]. From the atmosphere P. syringae can eventually bionucleate water to cause precipitation and fall with rain into a variety of environments $[3,8]$. Even though $P$. syringae can be found in the most disparate environments, it is still not clear how it survives or to what extent it undergoes evolutionary change. This latter point is particularly interesting because different stresses imposed on bacteria by changes in the environment or different biotic interactions can drive evolutionary change [9-11]. Moreover, the interaction with a wide range of bacteria can also open up a vast pool of genetic resources for horizontal gene transfer [12].

One area of particular interest is an understanding of how P. syringae can cope with predation stress. Nematodes, amoeba and insects are common inhabitants of soil, water courses and plants, so $P$. syringae will frequently encounter these predators and have likely evolved survival strategies. Nematodes and insects in particular are commonly used models for studying animal pathogens. Nematicidal activity has been reported for several environmental bacteria including P. aeruginosa [13]. $P$. aeruginosa can kill Caenorhabditis elegans in a few days (slow killing) when grown on minimal nutrient-poor medium, or in a few hours (fast killing) when grown on a nutrient-rich medium [14]. Modulating the virulence can be advantageous in vivo as the host can be used as a vector for spreading or surviving in adverse environmental conditions. More recently, a screen of several Pseudomonas species found a range of impacts on nematode development, killing and deterrence [15]. In that particular analysis, several P. syringae strains were observed to have weak or no effect on C. elegans egg laying or grazing.

Free-living protozoa, such as amoebae, are widespread in the environment, especially in water and can act as environmental reservoirs of food-borne pathogens [16]. Amoebic passage of Legionella pneumophila is reported to enhance bacterial survival [17]. Salmonella enterica can, for example, survive within Acanthamoeba polyphaga and A. rhysodes [18]. Recently, the SPI-1 type III protein secretion system has been implicated in $P$. fluorescens F113 resistance to amoeboid grazing [19].

In insects, P. syringae can survive ingestion by the pea aphid Acyrthosiphon pisum [20]. After ingestion, P. syringae replicated in the gut of the aphids and were subsequently secreted in the honeydew at a considerable distance from the original ingestion point, thus demonstrating an effective dispersal mechanism for the pathogen. This interaction appears to be a common trait in 
other plant pathogens, with Dickeya and Erwinia also able to survive ingestion and kill aphids [21,22]. A more common insect model used as an alternate host to analyse infection is that of the waxmoth Galleria mellonella. While this is usually used in a non-feeding state, by direct injection of bacteria into the haemocoel, it has nonetheless proved useful for identifying virulence factors $[23,24]$. One study found that $P$. fluorescens $\mathrm{CHA} 0$ and Pf-5 could kill G. mellonella after injection of the bacterium into the insect larvae [25]. This was found to be due to a single locus encoding the Photorhabdus luminescens $m c f$-like toxin P. fluorescens insecticidal toxin (Fit).

Identifying the genetic basis for bacterial interactions with alternative hosts, including predators, requires innovative methodologies. One such technique, a heterologous screening assay called Rapid Virulence Annotation (RVA) [26] was developed to identify putative bacterial genes conferring Gain of Toxicity (GOT) to the nematode C. elegans (nGOT), the protozoan A. polyphaga (aGOT) and the larvae of the wax-moth G. mellonella (iGOT). RVA has already been successfully adopted to find virulence islands in the dual insect and human pathogen Photorhabdus asymbiotica [26].

Taking advantage of the tools available to us, we therefore sought to characterize the interaction of three different $P$. syringae strains with C. elegans, A. polyphaga and G. mellonella. Once we established that the there was evidence of survival to the predators and toxicity in G. mellonella, we then carried out an RVA screen to identify candidate P. syringae cosmid libraries to find genes conferring survival/toxicity. Several genes putatively involved in the survival of predation and insect toxicity were examined to gain novel insight to how P. syringae can be surviving interactions with predators and alternate hosts.

\section{Materials and Methods}

\subsection{Bacterial Strains, Plasmids, Eukaryotes and Culture Conditions}

Bacterial strains and other organisms used in this study are listed in Table 1. Pseudomonas strains (P. syringae pv. tomato (Pto), P. syringae pv. phaseolicola (Pph) and P. syringae pv. aesculi (Pae)) were grown at $25^{\circ} \mathrm{C}$ in King's Medium B (KMB) [27] and Luria Bertani (LB) broth [28]. E. coli strains were grown at $37^{\circ} \mathrm{C}$ in LB media or broth. Antibiotics and supplements (Sigma-Aldrich, Gillingham, UK) were used to the following final concentrations: kanamycin $25 \mu \mathrm{g} \mathrm{mL}^{-1}$; tetracycline $10 \mu \mathrm{g} \mathrm{mL}^{-1}$; nitrofurantoin $10 \mu \mathrm{g} \mathrm{mL}^{-1}$. Bacterial cell titers for experiments were calculated using OD readings where a broth of $\mathrm{OD}_{600}$ value of 1.2 equates to $10^{9} \mathrm{cfu} \mathrm{mL}^{-1}$.

Table 1. Bacterial strains and invertebrates used in this study.

\begin{tabular}{ccc}
\hline Organism & Abbreviation & Relevant Characteristics \\
\hline Bacterial strains & & \\
Pseudomonas syringae pv. tomato DC3000 & Pto & Tomato pathogen [29] \\
Pseudomonas syringae pv. aesculi isolate P6617 & Pae & Isolated from horse chestnut in Glasgow, UK [30] \\
Pseudomonas syringae pv. phaseolicola strain 1448A & Pph & Bean pathogen [31] \\
Escherichia coli OP50 & E. coli & \\
\hline Invertebrates & & {$[26]$} \\
Acanthamoeba polyphaga & & {$[26]$} \\
Caenorhabditis elegans & & {$[26]$} \\
Galleria mellonella &
\end{tabular}

C. elegans were routinely propagated every week on nematode growth medium (NGM) [15] seeded with E. coli OP50 and incubated at room temperature. For sub-culturing a loop was used to collect nematodes from a week-old plate and transferred to a fresh NGM agar plate spread with OP50. Acanthamoeba polyphaga was grown in peptone yeast-extract glucose (PYG) medium [18] as a monolayer in a $50 \mathrm{~mL}$ Falcon tube at $23^{\circ} \mathrm{C}$. A. polyphaga was sub-cultured weekly by gently tapping flasks to detach cells before diluting 1:10 in fresh PYG medium. Stationary phase (3-5 days) cultures of A. polyphaga were used throughout this study by the following approach. A. polyphaga was harvested by gently tapping flasks, followed by centrifugation (3000 rpm, $5 \mathrm{~min}$ ) and washed twice in Page's amoeba saline (PAS) (2.5 mM NaCl, $1 \mathrm{mM} \mathrm{KH}_{2} \mathrm{PO}_{4}, 0.5 \mathrm{mM} \mathrm{Na}_{2} \mathrm{HPO}_{4}, 40 \mathrm{mM} \mathrm{CaCl}$, and $20 \mathrm{mM} \mathrm{MgSO}$ ) 
solution, before numbers were adjusted to $2 \times 10^{5}$ cells $\mathrm{mL}^{-1}$ using a haemocytometer for counting samples. G. mellonella were obtained from Livefood UK at L4 stage. The moth larvae were kept in the fridge at $4{ }^{\circ} \mathrm{C}$ for no longer than two weeks before their use, and once used in the experimental tests, kept at room temperature.

\subsection{Survival Assays against P. syringae Strains}

\subsubsection{Caenorhabditis elegans Killing Assay}

Approximately $100 \mu \mathrm{L}$ of an overnight culture of a P. syringae strain was spread onto NGM in $5.5 \mathrm{~cm}$ Petri plates and incubated at $27^{\circ} \mathrm{C}$ for $24 \mathrm{~h}$. After an additional $24 \mathrm{~h}$ at room temperature $\left(23-25^{\circ} \mathrm{C}\right.$ ) each plate was seeded with ten L4-stage hermaphrodite C. elegans nematodes. Plates were incubated at $25^{\circ} \mathrm{C}$ and examined for $C$. elegans viability every $24 \mathrm{~h}$ for 3 days. After incubation each C. elegans adult was assessed for response to touch (an indicator of life status). Non-movers following touching were scored as dead.

\subsubsection{Acanthamoeba polyphaga Growth Assay}

A population of $5 \times 10^{4}$ cells of $A$. polyphaga amoebae cells, previously grown for 4 days in PYG medium, were co-incubated for 0,12 and $24 \mathrm{~h}$ with $2 \times 10^{2} \mathrm{cfu} \mathrm{mL}^{-1} P$. syringae in phosphate buffered saline (PBS) [28]. E. coli OP50 was used as positive control. At the end of the co-incubation amoebae were sedimented by gentle centrifugation at $200 \mathrm{rpm}$ for $10 \mathrm{~min}$, rinsed three times in sterile water, re-eluted and serially diluted in PBS. Live amoebae were counted using a haemocytometer and original populations calculated using the dilution factor giving the most statistically accurate population count.

\subsubsection{Galleria mellonella Killing Assay}

A U-100 insulin syringe equipped with a 29-gauge needle (BD) was used to inject $10 \mu \mathrm{L}$ aliquots of a $1 \times 10^{6} \mathrm{cfu} \mathrm{mL} \mathrm{m}^{-1}$ bacterial inoculum in PBS or $10 \mathrm{mM} \mathrm{MgCl}_{2}$ into the haemocoel of each G. mellonella larvae via the last left proleg. Before and after injection, the area was cleaned using an alcohol swab. After injection, G. mellonella larvae were incubated in plastic containers and kept at room temperature in the dark. The number of dead larvae were scored daily for $72 \mathrm{~h}$. Larvae were considered dead when they displayed no movement in response to a stab to the head. The crude cell-free supernatant (derived by centrifuging and filtering $(0.2 \mu \mathrm{M})$ ) from an overnight $(\mathrm{O} / \mathrm{N})$ broth culture of the bacterial strains was also used to assess toxicity.

\subsection{Survival Assay of P. syringae against Caenorhabditis elegans and Acanthamoeba polyphaga In Vitro}

Overnight broths $(10 \mu \mathrm{L})$ of Pae, Pph or Pto were spotted onto individual $1 \mathrm{~mL}$ NGM agar volumes in 25 well plates (compartmentalized Sterilin ${ }^{\mathrm{TM}} 100 \mathrm{~mm}$ square Petri dishes, Thermo Scientific, Basingstoke, UK) and grown overnight. The following day C. elegans nematodes were washed from a 4-day old NGM plate using $1 \mathrm{~mL}$ PBS and a sterile glass spreader. Nematodes per unit volume were enumerated using light microscopy and approximately 30 adults were added into the top right corner of each well in the plate. Bacteria and nematodes were recovered from the plate after 0, 7 and 14 days using $1 \mathrm{~mL} 10 \mathrm{mM} \mathrm{MgCl}_{2}$, homogenized using sterile micropestles (Eppendorf, Hamburg, Germany). Samples were serially diluted in sterile water, plated on KMB supplemented with nitrofurantoin and bacterial colonies enumerated. Samples were done in triplicate for each time point. E. coli OP50 was used as a control strain. The same experiment was performed using A. polyphaga as predator. An aliquot of $10 \mu \mathrm{L}$ overnight broths of Pae, Pph or Pto were inoculated on PYG medium poured in 25 well plates (each well containing approximately $1 \mathrm{~mL}$ of medium) and grown overnight. The following day $10 \mu \mathrm{L}$ of a 7-day old culture of A. polyphaga (approximately $3 \times 10^{5}$ cells) were spotted in the centre of each well. Samples were done in triplicate for each time point. The bacteria and the A. polyphaga were recovered from the plate after 0 and 7 days using $1 \mathrm{~mL} 10 \mathrm{mM} \mathrm{MgCl}_{2}$, serially diluted in sterile water, plated on KMB and the bacteria counted. E. coli OP50 was used as a control strain. 


\subsection{Molecular Biology Techniques including Cosmid Library Creation and Sequencing}

Cosmid DNA was isolated from a pure bacterial culture using either a mini or midi prep kit (QIAGEN, Manchester, UK) and restriction enzymatic digests performed as per manufacturers protocols (NEB). Total DNA was extracted with a Puregene kit for Gram-negative bacteria (QIAGEN). A Pae P6617 cosmid library (1800 clones) was constructed using cosmid vector pIJ3200 as previously described [33] whereas two pLAFR3-based cosmid libraries (2000 clones each) of Pph 1448A and Pto DC3000 were already in existence. Each cosmid clone had an insert of between $30-40 \mathrm{~kb}$ for the $1448 \mathrm{~A}$ and DC3000 libraries and 10-40 kb for the Pae library, thus providing between 7.5 to 13 -fold genome coverage. Primers used in construction are listed in Supplementary Table S1. The end-sequencing for the cosmid was performed by Geneservice (Source BioScience, Oxford, UK) using primer pair pLAFR3Forint and pLAFR3IntRev for the library of $P p h$ and Pto which was constructed in pLAFR3 and primer pair T3 and T7 for the Pae library constructed in pIJ3200. Standard PCR reactions were performed using GoGreen Master mix (Promega, Madison, WI, USA) whereas BIO-X-ACT Short polymerase (Bioline, London, UK) was used for high fidelity amplifications; oligonucleotide primer pairs used per respective assay are listed in Supplementary Table S1. PCR fragments were purified from agarose gels by QIAquick columns (QIAGEN).

\subsection{RVA Analysis of Gain of Toxicity (GOT) Assays}

We adapted the Gain of Toxicity (GOT) method of Waterfield et al. [26] to carry out screens of $P$. syringae cosmid libraries in the presence of nematode or amoeba predation, or by injection to G. mellonella larvae. This technique occurs by screening fragments of a host genome (in this instance, cosmids containing genomic sections) within a susceptible host bacterium in the presence of the $C$. elegans or A. polyphaga predators, or within the haemocoel of the G. mellonella larvae. The methodology for each screening system is described below. Cosmids conferring Medium-Resistant survival/toxicity were chosen for end-sequencing. The end sequences were aligned to the genome sequences of the relevant strains using NCBI BLAST, and viewed using Artemis and Artemis Comparison Tool, allowing the cosmid gene content to be manually assessed. To simplify the downstream analysis, a scoring system was devised to rank cosmids where overlapping cosmids from the same GOT or cosmids that were selected from multiple GOT were priority targeted. A value of "1" was given to a gene every time it was represented in any of the GOT screens. Scoring higher than " 3 " (Supplementary Table S2) were considered for further "in silico" analysis to investigate the gene functions in detail.

\subsubsection{Caenorhabditis elegans ( $\mathrm{GGOT}$ )}

C. elegans was grown for 4 days at $18{ }^{\circ} \mathrm{C}$ in NGM seeded with E. coli OP50. The P. syringae cosmid libraries were grown in 96 wells plates on LB supplemented with tetracycline overnight and $10 \mu \mathrm{L}$ of each cosmid clone was placed in the middle of each well in a 25 well plate containing NGM supplemented with tetracycline. The plates were incubated at $37^{\circ} \mathrm{C} \mathrm{O} / \mathrm{N}$. C. elegans nematodes were washed from plate cultures, as above, using PBS and washed three times in PBS. The density of the nematodes was adjusted to 40 nematodes per $10 \mu \mathrm{L}$ and spotted in the corner of each well of the 25 wells per plate containing the library clones. The plates were incubated at room temperature and assessed over 11 days. The resistance of the cosmid colony in each plate was scored based on disappearance of the bacterial colony: disappearance after 1 day (Very Low resistance), 3 days (Low), 5 days (Medium), 7 days (High), 9 days (Very High); still present at 11 days (Resistant).

\subsubsection{Acanthamoeba polyphaga (aGOT)}

A. polyphaga was grown at $25^{\circ} \mathrm{C}$ for 7 days in PYG media and then diluted in fresh PYG media to reach a concentration of $2 \times 10^{5}$ cells $\mathrm{mL}^{-1}$. Forty eight colony arrays of each $P$. syringae cosmid library were replica plated onto $9 \mathrm{~cm}$ Petri dishes containing PYG agar [26] supplemented with tetracycline and grown at $37^{\circ} \mathrm{C}$ overnight. The following day $10 \mu \mathrm{L}$ volumes of $A$. polyphaga were spotted to each 
centre location within the array (i.e., 35 A. polyphaga spots within the 48 arrayed bacterial strains/clones) and incubated for up to 12 days at room temperature. The assessment started at 3 days, whereby plates were scored each day. The resistance of the cosmid colony in each plate was scored based on disappearance of the bacterial colony: disappearance after 3 days (Very Low resistance), 5 days (Low), 7 days (Medium), 9 days (High); 11 days (Very High); still present after 11 days (Resistant).

\subsubsection{Galleria mellonella (iGOT)}

The P. syringae cosmid libraries were grown in 96 well plates on LB supplemented with tetracycline at $37^{\circ} \mathrm{C}$ overnight and $5 \mu \mathrm{L}$ of each cosmid was injected by dipping a 25-gauge needle into a broth and stabbing the needle into the open blood system (haemocoel) of G. mellonella larvae in triplicate. The larvae were then kept in 25 well plates at room temperature and scored for 4 days. Colonies that caused mortality or morbidity or altered the health (melanization, and sluggish movement) of G. mellonella were retested. The toxicity of the cosmid colonies was scored based on time to death: larval death after $12 \mathrm{~h}$ (scored 1), 1 day (scored 2), 2 days (scored 3), 3 days (scored 4); 4 days (scored 5); still alive (scored 6). The approximate number of bacteria injected was pre-assessed by dipping the needle in an overnight broth, flushing the needle in sterile water, serially diluting in sterile water and plating onto LB agar supplemented with tetracycline.

\subsection{Gene Knock-Out Strategy to Create Mutants}

Knock-out mutants of $P$. syringae were constructed as follows: approximately 400 bp of DNA internal to each gene was amplified using a proofreading PCR enzyme and ligated into the vector pCR 2.1_TOPO. Each ligation was electroporated into electrocompetent E. coli TOP10 cells (Invitrogen, Carlsbad, CA, USA). Recombinant colonies were selected by antibiotic resistance, and the knock-out mutation was confirmed by PCR analysis using a combination of vector primers and gene specific primers.

\subsection{Biofilm and Swarming Characterisation of Mutants}

The biofilm formation assay was performed in 96-well polystyrene microtiter plates. The bacterial strains to be tested were grown overnight at $25^{\circ} \mathrm{C}$ or $37^{\circ} \mathrm{C}$ in LB broth and diluted 1:100 in fresh medium (to achieve $10^{7} \mathrm{cfu} \mathrm{\textrm {mL } ^ { - 1 }}$ ) into the 96-well plates the following morning. The plates were subsequently incubated at $27^{\circ} \mathrm{C}$ for $24 \mathrm{~h}$ without shaking. The amount of biofilm formation was determined by pouring out the contents of the wells and adding $200 \mu \mathrm{L}$ of $1 \%$ crystal violet to each well for 1 min before rinsing with water and eluting stain with 100\% EtOh for 5 min. The level of stain retained by cells was quantified by measuring the absorbance at $595 \mathrm{~nm}$. The swarming assay was performed using LB medium supplemented with $0.5 \%$ Bacto-Agar. The bacterial strains to be tested were transferred from an overnight culture plate using a sterile toothpick and cells stabbed into the centre of the soft agar; plates were incubated at $27^{\circ} \mathrm{C}$. The assays were performed independently at least three times and motility was scored as the distance in $\mathrm{cm}$ that the bacteria moved from the inoculum point to the edge of the growing area. Motility was assessed and recorded every $24 \mathrm{~h}$ for 7 days.

\subsection{Statistical Analyses}

Statistical analyses were performed using 2- (time and bacterial treatment) or single factor ANOVAs (bacterial treatment) using SAS statistical software (v 9.4) (Cary, MT, USA). Most analyses were followed by Tukey-Kramer adjusted multiple comparisons of the data, except for the characterization of the mutants (Figure 4), for which planned contrasts were made between each mutant and the Pto and E. coli controls thereby rendering comparisons as inconsequential between individual mutants. 


\section{Results}

3.1. Pseudomonas syringae Strains Affect the Survival of Caenorhabditis elegans, Acanthamoeba polyphaga and Galleria mellonella

We opted to study three P. syringae pathovars, Pto DC3000 a tomato pathogen, Pae P6617 a tree pathogen and Pph 1448A, a bean pathogen. Each strain was originally isolated from very different environments and we postulate that as such they may have evolutionary adaptations for those niches. Furthermore, genomic analysis of these three pathovars Pto DC3000 [29], Pae P6617 [30] and Pph 1448A [31] has revealed they are also phylogenetically distinct. Our first analysis was to determine the outcome of the wild-type bacterial interaction with each predator taxa. Each assay differed slightly in the measured outcomes due to the nature of the organism being used; nematodes were tested by feeding and touch response, amoeba by grazing and increase in numbers, Galleria larvae by injection and touch response.

Ten L4 stage C. elegans adults were incubated with a lawn of Pae, Pto, Pph or E. coli OP50 on an NGM agar plate for $72 \mathrm{~h}$. All three P. syringae strains exhibited weak, yet statistically better, killing of C. elegans compared to the E. coli OP50 control. Pae was most effective, killing 3/10 (30\%) of the nematodes compared to 1.3/10 (13\%) for both Pto and Pph (Figure 1A). In bacteria and amoeboid co-cultures, and starting from known inoculation loads, A. polyphaga populations after $24 \mathrm{~h}$, whilst higher in each respective case, were significantly lower when in the presence of the P. syringae strains compared with E. coli OP50 (Figure 1B).

The final test was to assess the effect of bacteria on insect larvae after injection. Both bacterial cells and cell-free supernatant from an overnight bacterial culture were injected into the haemocoel of G. mellonella and larval mortality scored after 24 and $72 \mathrm{~h}$ (Figure 1C). All the P. syringae strains triggered a strong immune response after $8 \mathrm{~h}$ as evidenced by melanisation of the larvae; followed by death after $72 \mathrm{~h}$. The extent of the response was observed to be dose dependent, with the higher titre of cells resulting in increased mortality. All three Pseudomonas strains led to significantly higher numbers of dead larvae compared to the E. coli OP50 negative control strain. The supernatant from an overnight culture of the same strains was also used to assess if any toxic compound(s) had been released by the bacterial cells into the extracellular milieu. In these experiments a similar pattern of toxicity was observed $72 \mathrm{~h}$ post-injection i.e., supernatants from all P. syringae strains were statistically more toxic than E. coli. This is consistent with the hypothesis that at least some component(s) of the P. syringae pathological effects may be the result of secreted virulence factor(s).

\subsection{Pseudomonas syringae Survival against Caenorhabditis elegans and Acanthamoeba polyphaga}

It is a reasonable hypothesis to propose that the negative impact of the $P$. syringae strains on C. elegans relates to strategies that have evolved to survive predation in the environment. Limiting toxicity to the host but at the same time surviving predation can be an important step for bacterial dispersion in the environment and colonization of new hosts [34]. Therefore, we decided to evaluate if the bacterial cells themselves were able to directly resist predation. To test strain survival following predatory challenge with C. elegans, $10 \mu \mathrm{L}$ of $1 \times 10^{8} \mathrm{cfu} \mathrm{mL}^{-1}$ Pae, Pto, Pph and E. coli OP50 were co-incubated on an NGM agar plate together with $10 \mathrm{~L} 4$ stage C. elegans adults. Sets of plates were incubated at $23^{\circ} \mathrm{C}$ for 7 and 14 days after which time the bacteria were recovered and the survivors enumerated. Significant differences in survival of the P. syringae strains compared to E. coli OP50 were observed after 7 and 14 days (Figure 2A). These results clearly indicate that nematode predation does reduce all the bacterial populations tested, but also that all three $P$. syringae strains tested were capable of resisting C. elegans predation to a greater degree than E. coli OP50. Furthermore, in experiments designed to assess the impact of $A$. polyphaga grazing, we again observed that while the amoebae were able to reduce numbers of all bacterial strains tested, the E. coli OP50 control exhibited a larger reduction in population size compared to the P. syringae strains (Figure 2B). Taken together, these 
results are consistent with the hypothesis that $P$. syringae has evolved anti-predation mechanisms for nematodes and amoeba, and also secretes one or more virulence factors toxic to an insect.

A

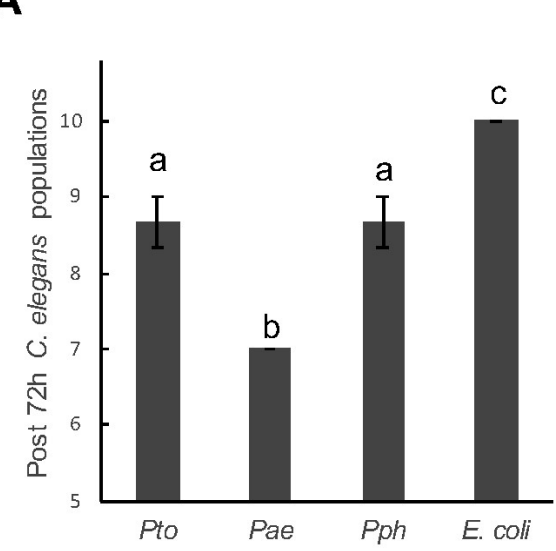

B

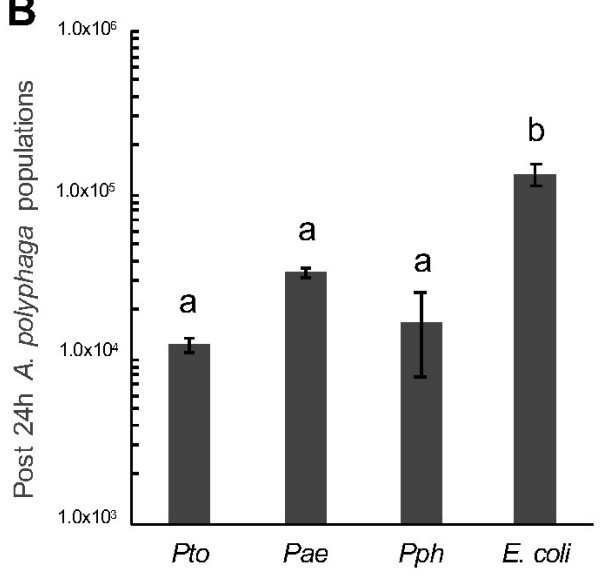

C

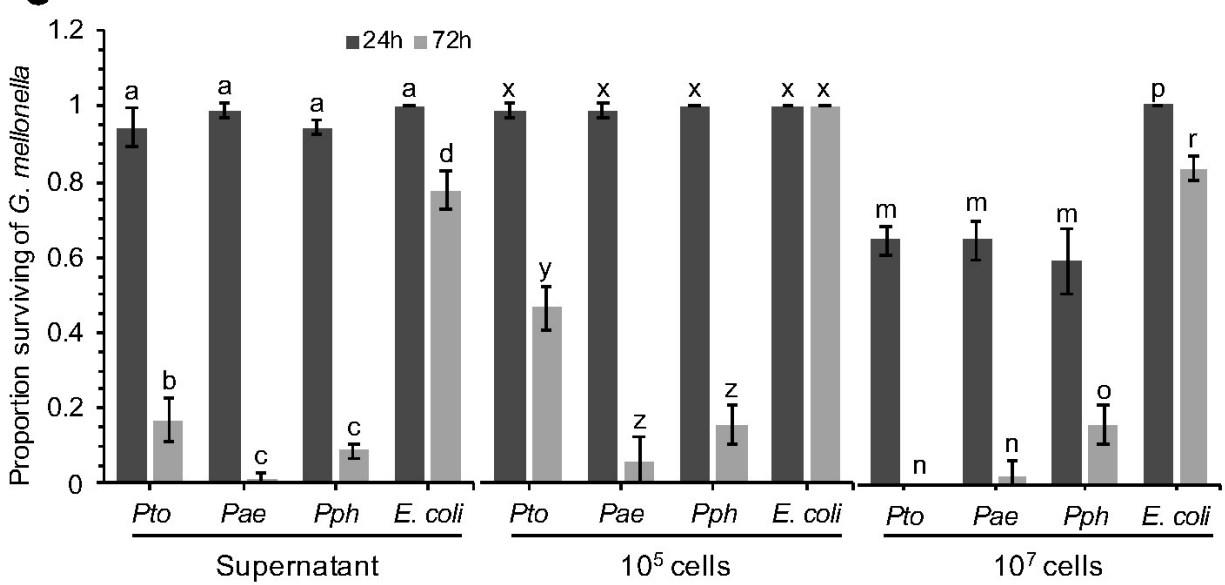

Figure 1. Temporal effect of Pseudomonas syringae strains on population sizes of Caenorhabditis elegans and Acanthamoeba polyphaga, and mortality of Galleria mellonella. (A) With initial populations of $10 \mathrm{~L} 4$ stage C. elegans, data shows number of C. elegans alive after $72 \mathrm{~h}$, when challenged with Pto, Pae, Pph and E. coli control. ANOVA detected statistically significant differences $(p=0.0002, \mathrm{df}=8) ;(\mathbf{B})$ With initial populations of $1.2 \times 10^{4} \mathrm{~A}$. polyphaga cells, data shows numbers of $A$. polyphaga cells after $24 \mathrm{~h}$ when co-cultured in presence of Pto, Pae, Pph and E. coli control. ANOVA detected statistically significant differences $(p=0.0008, \mathrm{df}=8)$; (C) Quantitative analysis of $G$. mellonella mortality by $P$. syringae, survival rate represents the relative number. Treatment type (supernatant, $10^{5}$ and $10^{7}$ cells), was analyzed separately by 2 -factor ANOVA. An interaction between time and $P$. syringae treatments resulted in multiple comparisons for all types of treatment $(p<0.0001, \mathrm{df}=16)$. For all panels, bars represent the mean of 3 replicates, error bars represent standard error of the mean. Comparison of means by Tukey-Kramer HSD are shown as letters above bars, where different letters indicate statistically significant differences $(p<0.05)$. 
A

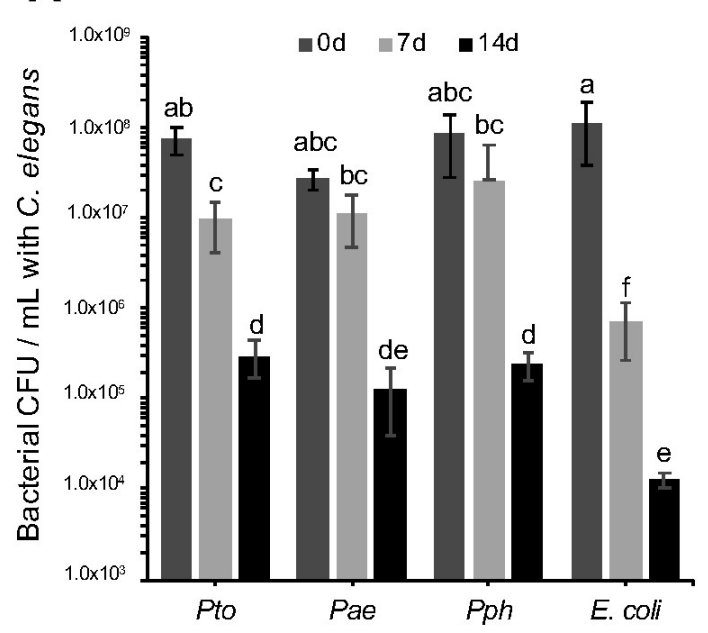

B

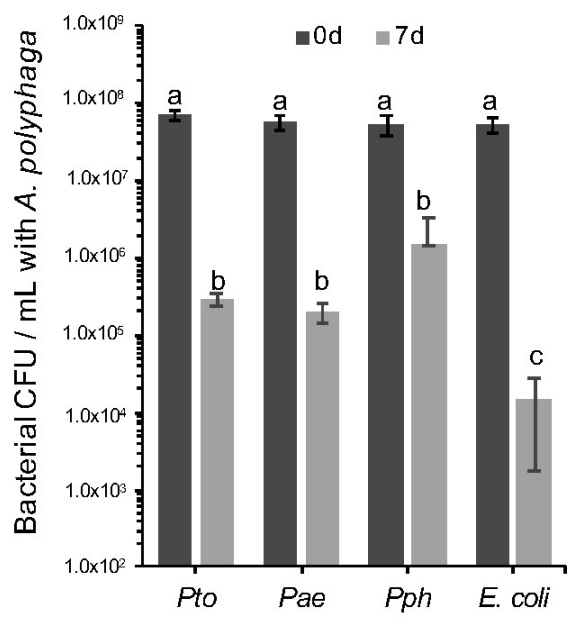

Figure 2. Survival of Pseudomonas syringae strains upon predation by Caenorhabditis elegans and Acanthamoeba polyphaga. (A) Pto, Pae and Pph were assessed for survival upon C. elegans predation. Bacterial populations were assessed after 0, 7 and 14 days of co-incubation with $10 \mathrm{~L} 4$ stage C. elegans. A 2-factor ANOVA detected statistically significant differences and showed an interaction between the time and treatment factors ( $p=0.0007 \mathrm{df}=24)$; (B) Pto, Pae and Pph were assessed for survival when challenged with $A$. polyphaga. Bacterial population were assessed after 0 and 7 days of co-incubation with $3 \times 10^{5}$ A. polyphaga cells. ANOVA detected statistically significant differences $(p=0.0002 \mathrm{df}=16)$. For all panels, bars represent the mean of 3 replicates and error bars indicate the standard error of the mean. Multiple comparison of means by Tukey-Kramer HSD are shown as letters, where different letters indicate statistically significant differences $(p<0.05)$.

\subsection{RVA Analysis of Pseudomonas syringae pv. tomato, Aesculi and Phaseolicola Cosmid Libraries Determine} Gain of Toxicity (GOT)

Earlier experiments indicated that all $P$. syringae strains were phenotypically better at either surviving predation by nematodes or amoeba, or killing Galleria, than E. coli OP50. To identify the genetic basis of these differences, the cosmid libraries of the three P. syringae strains were screened in each GOT assay, assessing individual clones for E. coli GOT. For both Pto and Pph, 2000 cosmid clones were screened while 1800 were screened for Pae. The GOT assays used were identified as nGOT (using the nematode $C$. elegans), aGOT (using the amoebae A. polyphaga) and iGOT (using the insect $G$. mellonella). The ability to survive predation by either C. elegans or A. polyphaga is shown in Figure 3A,B respectively, while the G. mellonella killing assay is shown in Figure 3C.

Based on the GOT assays, the Pto library yielded the highest number of predation resistant clones for each predator. Out of the 2000 cosmid clones tested in each GOT screening, 201 Pto clones were scored as positive for increasing E. coli resistance to predation. We obtained 99 positive clones from the Pae library and 74 from the Pph library (Table 2). These differences point to the already established genetic variation between strains, or alternatively, that there were distinct levels of enrichment of particular genomic regions during the library construction process. If the results are analyzed in respect to the specific GOT assays we see that the Pph and Pae cosmid libraries showed a higher number of cosmids conferring resistance against $A$. polyphaga followed by comparable numbers showing resistance against $C$. elegans and toxicity against $G$. mellonella. Conversely, the number of clones obtained from the Pto library were relatively higher against G. mellonella, but lower against C. elegans and A. polyphaga. Again, it is not clear if this reflects different genomic content of the strains or strain specific cryptic bias in cosmid construction. 

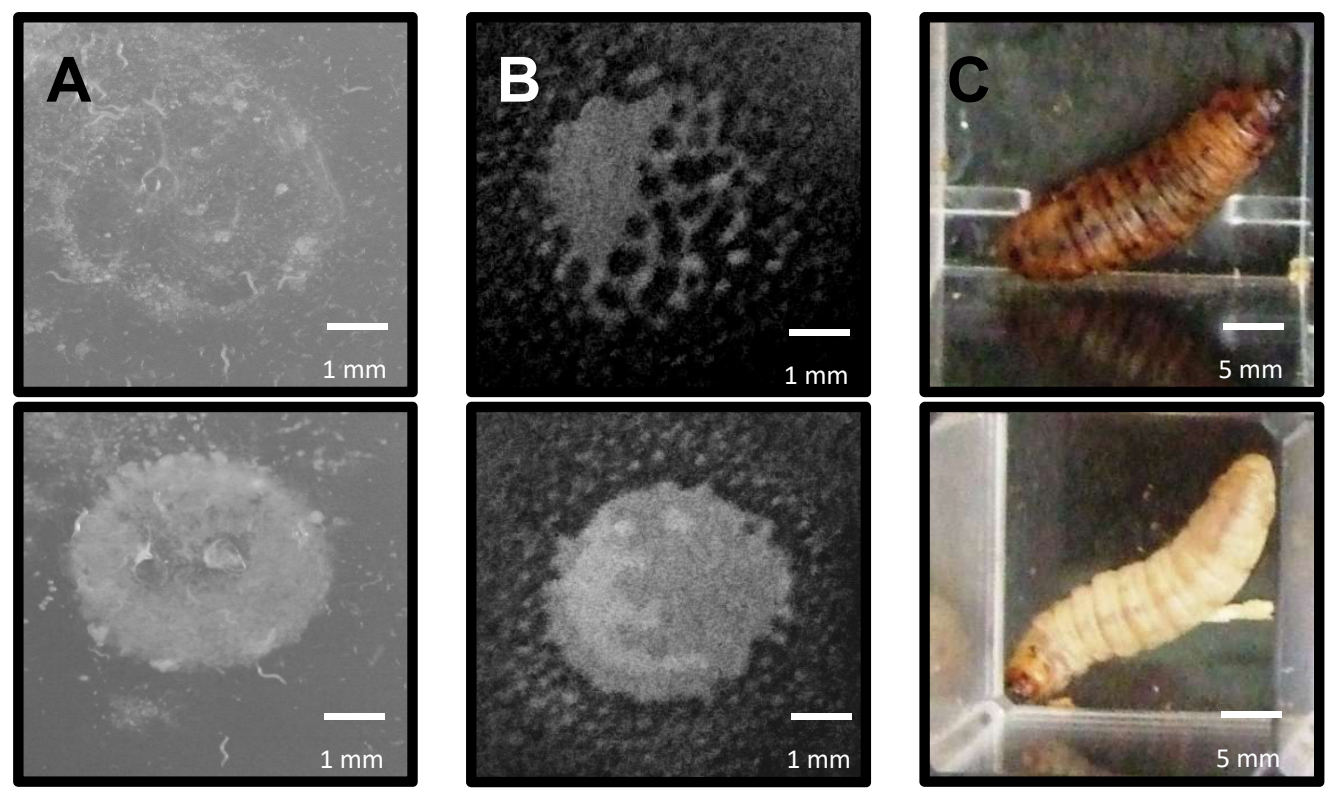

Figure 3. Examples of observed predation by Caenorhabditis elegans, Acanthamoeba polyphaga and gain of toxicity (GOT) against Galleria mellonella of bacterial strains during RVA assays. (A) nGOT assay. Colonies carrying $P$. syringae genes (as cosmid clones) not involved in survival were eaten by C. elegans within $72 \mathrm{~h}$ (top) but those with genes involved in resistance were able to resist predation for longer (bottom); (B) aGOT assay. Colonies carrying genes not involved in survival were gradually eliminated by $A$. polyphaga within 7 days (top), but those which carried genes involved in resistance were able to resist predation for longer (bottom); (C) iGOT assay. Colonies carrying genes conferring an increase in toxicity were capable of killing G. mellonella within $48 \mathrm{~h}$ (top) while others were unable to kill the larvae (bottom). Scale bars in white.

Table 2. Summary of positive cosmid colonies isolated from each GOT screen after challenge against Caenorhabditis elegans and Acanthamoeba polyphaga, and the Galleria mellonella killing assay.

\begin{tabular}{|c|c|c|c|c|c|c|}
\hline \multicolumn{7}{|c|}{ Degree of Resistance (days) } \\
\hline nGOT $^{1}$ & Very low (1) & Low (3) & Medium (5) & High (7) & Very high (9) & Resistant (11) \\
\hline Pto & 20 & 15 & 5 & 1 & 5 & 4 \\
\hline Pph & 0 & 0 & 2 & 3 & 2 & 2 \\
\hline Pae & 5 & 10 & 3 & 2 & 4 & 1 \\
\hline aGOT $^{2}$ & Very low (3) & Low (5) & Medium (7) & High (9) & Very high (11) & Resistant (11+) \\
\hline Pto & 15 & 10 & 4 & 1 & 2 & 2 \\
\hline Pph & 39 & 5 & 1 & 6 & 1 & 2 \\
\hline Pae & 25 & 20 & 0 & 2 & 1 & 2 \\
\hline \multicolumn{7}{|c|}{ Degree of Virulence (days) } \\
\hline iGOT $^{3}$ & Very low (0.5) & Low (1) & Medium (2) & High (3) & Very high (4) & Virulent $(4+)$ \\
\hline Pto & 60 & 20 & 7 & 13 & 10 & 7 \\
\hline$P p h$ & 0 & 0 & 3 & 5 & 2 & 1 \\
\hline Pae & 4 & 3 & 4 & 8 & 4 & 1 \\
\hline
\end{tabular}

1,2 The numbers of cosmids were clustered for their resistance phenotypes in the C. elegans (nGOT) and A. polyphaga (aGOT) assays based on the relative disappearance of their respective bacterial colony over time. Degrees of resistance (Very low to Resistant) have been scored on a persistence over time scale; numbers in brackets represent days, e.g., (5) is 5 days. ${ }^{3}$ In the G. mellonella (iGOT) killing assay, all cosmids were clustered on their toxicity phenotype. The degree of toxicity (Very low to Virulent) was classified on the death phenotype caused by the cosmid clone within G. mellonella over time; days in brackets, e.g., (2) is 2 days. The toxicity of the cosmid colonies was scored based on time to death: still alive (scored 0.5); 4 days (scored 1); 3 days (scored 2); 2 days (scored 3); 1 day (scored 4); after $12 \mathrm{~h}$ (scored 4+). Pseudomonas syringae pv. tomato (Pto), phaseolicola (Pph) and aesculi (Pae). 


\subsection{Sequencing and Bioinformatic Analysis of RVA's Positive Cosmid Clones}

The cosmid clones scoring a positive phenotype of medium resistance/toxicity (or greater) from the RVA screening were selected for insertion-end sequencing. Sanger sequencing, using the forward and the reverse primers on the cosmid vector was used to determine the first 800-1000 bp of each cosmid insert. Overall 65 cosmid clones were successfully sequenced from the iGOT assay, 24 from the aGOT assay and 34 from the nGOT assay. Prioritization of analysis was given to those cosmid clones that scored as a 3 (see Section 2), whereby common genes were emerging from the GOT screens. This indicated that a number of individual P. syringae genes or gene systems were contributing to E. coli survival or toxicity. Another interesting observation was that several potential virulence genes were present in more than one P. syringae strain which may indicate that their function is conserved among the different strains. Supplementary Table S2 summarizes the best hits found from the RVA using Pto as a reference strain and compared for presence/absence in Pph and Pae RVA's screening.

\subsection{Validation and Characterisation of Genes Identified by RVA}

Although the RVA analysis allows for the rapid screening of genotype/phenotype relationships, the trade-off is that each cosmid encodes for between 15-40 genes, any one or cluster of which could be conferring the GOT phenotype to the E. coli host strain. To rationalize a set of candidates for validation, we focused on genes that were positively scored in more than one GOT assay and for more than one strain; these were pslA, fleQ, pilj, cheW, PSPTO_0373 (rhsD), and hlyD (Table 3). Since we were using RVA as a tool to inform us about putative genes contributing to $P$. syringae ecological success, we focused on making insertional gene knock-outs in Pto strain DC3000 since this strain is particularly amenable to genetic manipulation. Insertional mutants for all genes were accomplished except for the cheW and hlyD genes. As an alternative we therefore created, che $A$ and hlyIII mutants to act as surrogate functional comparators. Gene complementation was not done since mutations in gene clusters (potentially causing polar effects) were deemed acceptable means of knocking out gene function as were knock-outs of orphan genes.

Table 3. List of mutants created following selection of target genes by Rapid Virulence Annotation (RVA) analysis. .

\begin{tabular}{cccc}
\hline Mutant & Gene & Function & GOT \\
\hline Pto::algD & algD (PSPTO_1243) & Alginate biosynthesis & Control mutant for GOT assays \\
\hline Pto::fleQ & fleQ (PSPTO_1954) & Transcriptional regulator, flagella regulation & nGOT/iGOT \\
\hline Pto::pslA & pslA (PSPTO_3529) & Exopolysaccharide biosynthesis and biofilm formation & nGOT/iGOT \\
\hline Pto::pilJ & pilJ (PSPTO_5031) & Type IV pilus biogenesis & nGOT/aGOT \\
\hline Pto::cheA & cheA (PSPTO_0913) & Chemotaxis & nGOT/aGOT (for cheW) \\
\hline Pto:::rhsD & rhsD (PSPTO_0373) & Rearrangement hotspot family protein & nGOT/iGOT \\
\hline Pto::hlyIII & hlyIII (PSPTO_5077) & Haemolysin & aGOT/nGOT (for $h l y D)$ \\
\hline
\end{tabular}

\subsection{Survival and Toxicity Characterisation of Mutants against C. elegans, A. polyphaga and G. mellonella}

The survival of all the mutants described in Table 3 was assessed against C. elegans (Figure 4A) and A. polyphaga (Figure 4B) using the same approach as described in Section 3.2. Their toxicity against G. mellonella was also assessed as described in Section 3.1 (Figure 4C). Statistical analyses using planned contrasts between each mutant and wild-type Pto and E. coli were performed in order to determine significant differences. Note, we do not believe there is any reasonable logic or statistical sense in comparing individual mutants. 

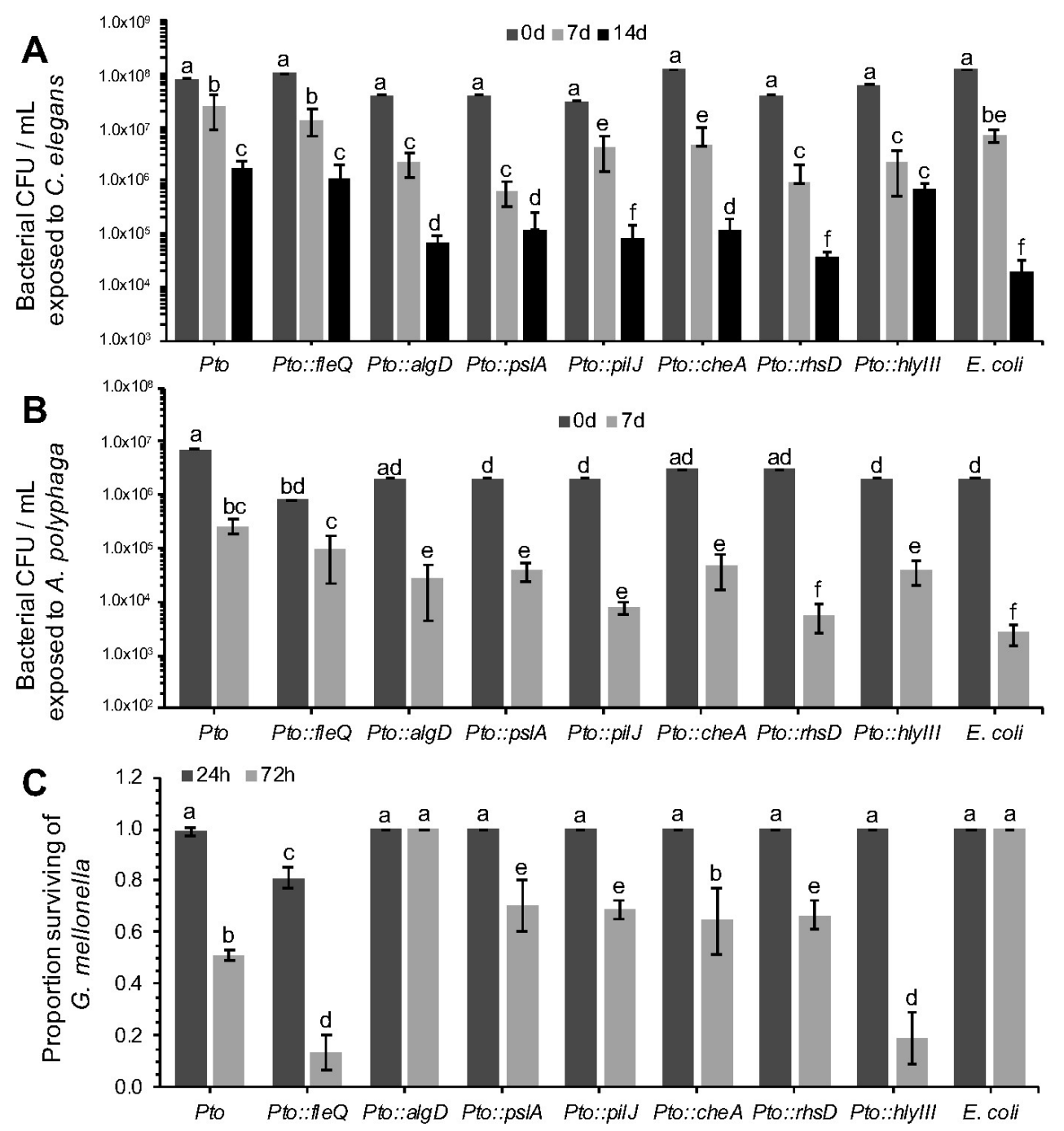

Figure 4. Characterization of Pto mutant survival after predation by Caenorhabditis elegans and Acanthamoeba polyphaga and killing of Galleria mellonella. See Table 3 for mutant descriptions. (A) Strains were assessed for survival against C. elegans predation. Bacterial populations were assessed after 0,7 and 14 days of co-incubation with $10 \mathrm{~L} 4$ stage C. elegans. 2-factor ANOVAs detected statistically significant differences $(p<0.0001, \mathrm{df}=18)$; (B) Strains were assessed for survival when challenged with $A$. polyphaga. Bacterial populations were assessed after 0 and 7 days of co-incubation with $3 \times$ $10^{5}$ A. polyphaga cells. 2-factor ANOVAs detected statistically significant differences $(p<0.001 \mathrm{df}=12)$; (C) Quantitative analysis of G. mellonella killing by Pto mutants ( $10^{5}$ cells). 2-factor ANOVAs detected statistically significant differences $(p<0.0001 \mathrm{df}=12)$. For all panels, bars represent the mean of 3 replicates and error bars indicate the standard deviation. Statistical differences were determined by contrasting each individual mutant to the Pto and E. coli controls, therefore different mutants cannot be compared between them but only to the controls themselves. Differences are shown as letters $(p<0.05)$.

In the predation assay with C. elegans and A. polyphaga, Pto::pslA exhibited a significant reduction in survival compared to the wild type. After seven days there was 1.5 to 2-log of difference between Pto and Pto::pslA. When tested in the G. mellonella killing assay statistically significant differences in mortality of the larvae were recorded between the Pto and Pto::pslA. After $72 \mathrm{~h}$ the Pto::pslA mutant was $50 \%$ less virulent than Pto.

The Pto::fleQ exhibited no difference in C. elegans or A. polyphaga grazing resistance phenotype compared to Pto wildtype, despite the flg genes being identified from the nGOT screen. However, when Pto::fleQ was tested in the toxicity assay against G. mellonella (Figure 4C), the results obtained 
were surprisingly different from expectations because the mutant was hypervirulent compared to the wild type. Significant differences were already noticeable after $24 \mathrm{~h}$ from the inoculation time as $30 \%$ of the larvae had already being killed by the mutant compared to a $1 \%$ death rate in the Pto wild type. After 72 h, Pto::fleQ had killed $87 \%$ of the larvae compared with $49 \%$ killed by Pto, while no death was recorded in the E. coli OP50 control. FleQ directly influences the expression of several genes including the alginate gene $\operatorname{alg} D$ [35]. The role of alginate in plant infection is well documented [36,37], but there is no evidence of $P$. syringae using it as a virulence mechanism against invertebrates; although previous work has described alginate importance in virulence of $P$. aeruginosa $[35,38]$. The increased virulence of Pto::fleQ may be due to a hyperproduction of alginate as the down-regulation of algD is suppressed. To test this hypothesis, a Pto::algD mutant, unable to produce alginate, was assessed for toxicity against G. mellonella. Pto::algD completely failed to kill the larvae over a period of $72 \mathrm{~h}$ (Figure $4 \mathrm{C}$ ). The data presented in this experiment appear to indicate that alginate is a product that triggers the immune system of G. mellonella leading to insect death. The poly-negative charge on the alginate [39] is likely to act to "mop up" innate immune cationic antimicrobial peptides [40].

E. coli containing cosmids carrying either the che (chemotaxis) or the pil (pilus formation) clusters had increased resistance to predation when compared to the E. coli wild type in the nGOT and aGOT assays. Two genes, respectively controlling pilus formation (pilJ) and chemotactic response (che A) in Pto were mutated. Strain Pto::pilJ and Pto::cheA both exhibited a significant reduction in survivability compared to Pto during challenge with C. elegans and A. polyphaga (Figure 4).

Gene PSPTO_0373, encoding an Rhs (Rearrangement Hotspot) factor [41], was found on a cosmid that conferred increased survivability to E. coli when challenged by C. elegans and A. polyphaga. Rhs genes are also present in P. aeruginosa and other Pseudomonas species [42]. The function of many rhs elements is still unclear but some evidence suggests that in P. savastanoi they can facilitate bacteriocin production [43]. In P. aeruginosa several rhs elements have been shown to enhance colonisation ability of the pathogen in patients with cystic fibrosis [44]. More recently RhsT has been shown to activate the inflammasome following translocation of the protein into phagocytic cells and leading ultimately to the death of these cells [45]. When predated in vitro by C. elegans, Pto::rhsD was significantly compromised in survivability (Figure 4A). The total population decreased by more than 1 log fold compared to Pto in $72 \mathrm{~h}$. Functional impairment in $r h s D$ was even more apparent in A. polyphaga competition trials where, after 7 days of incubation, survivability rate of the mutant was comparable to E. coli OP50 and exhibited a significant decrease in cell numbers compared to the wild type Pto strain (Figure 4B).

The hlyD gene, identified in the Pto screen, was found to confer higher survivability to E. coli in the aGOT and nGOT assays. The putative product of this gene, HlyD, is related to the type I secretion membrane fusion protein, an ABC transporter. Haemolysins are a general class of toxins secreted by a range of pathogenic bacteria to lyse host cells [46]. Despite several attempts, the creation of an hlyD mutant was unsuccessful. However, a related haemolysin, hlyIII (PSPTO_5077), was identified and a Pto::hlyIII mutant was created and tested in a competitive assay against all three invertebrates. Survivability of Pto::hlyIII, compared to Pto, was reduced in C. elegans after 3 days, but not 7 days (Figure 4). Hypervirulence, similar to that seen in Pto::fleQ, was observed in Pto::hlyIII with a rapid initial die-off and a significantly higher G. mellonella death rate after $72 \mathrm{~h}$.

\subsection{Further Characterisation of Mutant pslA}

The previous experiments enabled the identification of genes potentially involved in conferring insect killing or survival to grazing. There are a raft of further tests that can now be done to understand the likely function of these gene systems. One approach would be to carry out further phenotypic analysis. For example, the RVA screening revealed that the E. coli cosmid clone containing the psl operon from Pto was more resistant in the nGOT assay and more toxic in the iGOT assay. The psl gene cluster was first identified in P. aeruginosa and consists of 15 genes involved in EPS (exopolysaccharide) biosynthesis and biofilm formation [47]. In P. aeruginosa pslA is the first gene of the operon, and knockout mutants display decreased adhesion ability and reduced biofilm formation on different 
surfaces [47]. Pto possesses a similar organization of the $p s l$ cluster and shares a high identity with that of $P$. aeruginosa. We can therefore hypothesize that the pslA cluster is important for Pto biofilm formation, which may be important for the nematode and insect interaction. To assess the contribution of $p s l A$ to Pto biofilm forming ability, early-stage biofilm formation was assessed by measuring adhesion of Pto::pslA to polypropylene. While the wildtype showed a certain level of adhesion, ability of Pto::pslA strain was compromised and was comparable to a sterile growth medium (LB) control, indicating, at least in this experimental context, that psl is crucial for biofilm production in Pto (Figure 5).

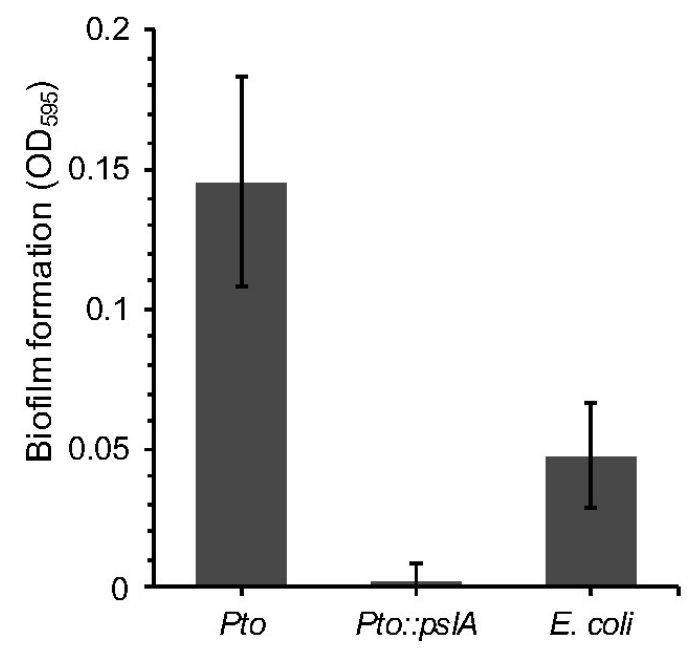

Figure 5. A Pseudomonas syringae pv. tomato strain DC3000 pslA mutant. Pto::pslA was assessed for the ability to form biofilms using crystal violet staining and measure of absorbance. ANOVA detected statistically significant differences $(p=0.0009 \mathrm{df}=9)$.

\section{Discussion}

The widespread occurrence of the plant pathogenic bacterium $P$. syringae in different habitats suggests the pathogen has a remarkable capacity to survive a breadth of environmental challenges. We hypothesized that one ability would be to withstand ingestion by predators and the insect haemocoel as a model for alternate hosts. We therefore aimed to determine the fate of different P. syringae strains, isolated from different geographical regions and host plants, after challenge with grazing predators and an insect larva. We first adapted a screening system used with an insect pathogen, Photorhadbus asymbiotica, to test the outcomes of challenge with nematodes, amoeba and insect larvae [26]. This involved monitoring and measuring the populations of predatory nematodes and amoeba, and also their bacterial prey numbers, after grazing on three $P$. syringae strains and for comparison a non-pathogenic E. coli strain, which is an innate food source for both predators.

Nematode populations were smaller after $72 \mathrm{~h}$ of grazing on P. syringae compared to E. coli, but nematode growth was especially poor after challenge with the horse chestnut pathogen, Pae. Mean length of nematodes brought up on respective diets of the three P. syringae strains were shorter than those brought up on E. coli with Pae-fed nematodes being, statistically, the shortest overall (data not shown). This adds weight to the idea that the three trialed P. syringae isolates each had a detrimental effect on the physiology of $C$. elegans by affecting life history traits ultimately impairing development. A similar, recent study on nematodes grown on lawns of $P$. fluorescens NZ17 found that the nematodes initially investigated but then actively avoided the bacteria on the plate which led to impairment in nematode growth and indeed death of these after a few hours if conducted on certain laboratory media [15].

The differential effect of bacterial species as a food source on C. elegans growth and health, whether this be positive or negative, is already well characterized; and this generally being dependent on the genetic makeup of the respective bacterial species [48]. Bacteria are able to provide essential macro 
and micronutrients and, via excretion, a range of other peptides to support growth of C. elegans. For example, the quorum-sensing pentapeptide competence and sporulation factor (CSF) and nitric oxide (NO), both secreted by Bacillus subtilis were found to extend longevity of C. elegans by downregulating an insulin-like signaling pathway [49]. On the other hand, bacterial species can be highly pathogenic to C. elegans as demonstrated by the secretion of a number of toxins by a Burkholderia cepacia complex [32] which resulted in high nematode mortality. Interestingly, the authors found that nematodes pre-raised on toxic B. cenocepacia cells were more inclined to continue consuming these even when a co-culture of these toxic cells mixed with a non-toxic E. coli strain was presented implying possible manipulation of nematode feeding behavior by bacteria. This suggests that the reduced size of the nematodes in the present study is not down to an avoidance of "unsavoury" P. syringae cells and thus a reduction in calorie intake but indeed a physiological effect due to ingestion of these cells. It must be noted that other authors have found C. elegans to actively avoid toxic bacterial cells but only in preference to other food sources [50,51].

The P. syringae and E. coli populations all fell over time, indicating the nematodes were reducing the bacterial population. However, the P. syringae bacterial numbers were significantly higher than the E. coli strain, thus showing a correspondence with the nematode abundance drop. Notably, the Pae population was not significantly larger than the other pathovars, suggesting the differential in nematode numbers with Pae was more likely due to a more potent toxic effect. The bacterial-amoebal challenge reflected similarities to that seen with the nematode analysis-that amoebal populations were less effectively supported by the P. syringae strains compared with E. coli, and that the P. syringae populations were reduced, but to a lesser extent compared to E. coli. This may again point to the production and secretion of toxins, in bacterial strains encoding greater virulence mechanisms, into the extracellular milieu. Increased persistence of bacteria in soil both in terms of competition against other endogenous bacterial strains [52] and as an avoidance mechanism to protozoan grazing [53] has already been attributed to the production of potentially toxic compounds. Pseudomonas fluorescens CHA0, for example, produces the protease AprA which provoked significant encystation of the amoeba Vahlkampfia sp. upon comparison to its isogenic mutant [54].

The third test analyzed the outcome of bacterial injection to the haemocoel of G. mellonella. Although this is a somewhat artificial screening system (as the insect would not be expected to ingest these bacteria in its natural honeybee parasitism habitat), it does provide a useful model for examining bacterial survival of the insect immune system. A dose-dependent effect was observed for P. syringae, with all three strains rapidly killing the larvae, whereas the E. coli had little or no toxic effect. Interestingly, the injection of spent bacterial broth (supernatant after removal of cells) resulted in larval death, suggesting that at least part of the action was based on a secreted product. Production of the TccC protein by P. taiwanensis has already been investigated for its strong insecticidal activity on several insect genera and most notably the larva of the diamond back moth Plutella xylostella [55]. Larvae of both G. mellonella and Manduca sexta are known to melanize and experience loss of cellular turgidity in the presence of $P$. fluorescens insecticidal toxin (Fit) [25]. Note that we did not test supernatants against nematodes or amoeba due to the nature of the tests being employed. The fast replication rate of the microbial predators would potentially have negated the ability to detect toxins that were not being renewed unless these were acutely potent.

The ability to kill insects and more effectively survive grazing suggested therefore that Pseudomonas encoded specific mechanisms for these phenotypes. This was directly tested by using E. coli-based cosmid libraries containing genomic regions of the three pathovars in the three GOT tests, to see if any of the genomic regions could enable improved E. coli survival. A large-scale screening was carried out testing 5800 cosmid clones in each GOT. The Pto library resulted in a higher number of positives (201) compared with Pae (101) and Pph (74). This does not appear to reflect over-representation of cosmids in the library because the same cosmid was not isolated repeatedly. More Pto cosmids were found for the nGOT, and strikingly, the iGOT analysis, whereas less Pto cosmids were found for aGOT. To aid the analysis, we focused on the cosmids displaying the most prominent 
GOT phenotypes and end sequenced 123 cosmids to map the genes found in each one. A wide range of genes with various metabolic, adhesive, virulence, cellular transport, biofilm formation, secretory, regulatory and those with an unknown function were observed with a summary of best hits from the BLAST analysis listed in Supplementary Table S2. To facilitate further investigation, we chose a sub-set of these gene systems and validated our selection by choosing only those which had been positively identified in more than one GOT assay and for more than one strain of $P$. syringae. The six more promising genes identified via this selection process were $p s l A$, fleQ, pilJ, cheW, rhsD and hlyD. A set of six insertional knockout mutants was created in Pto with cheA and hlyIII mutants to replace cheW and $h l y D$, respectively, as surrogate functional comparators due to difficulties in chromosomal manipulation at these two loci.

The ability of Pto::pslA to withstand both predation by C. elegans and A. polyphaga and cause mortality in G. mellonella was attenuated. The psl gene cluster, of which pslA forms part of, is known to be important in the production of exopolysaccharide biosynthesis and biofilm formation $[47,56]$. Biofilms may act as barriers preventing ingestion of bacteria by invertebrates. A biofilm produced by Yersinia pestis inhibited feeding by C. elegans by obstructing passage to the gut [57]. Protozoan grazing of Vibrio cholerae was reduced in cells protected within the matrix of a biofilm whereas their planktonic counterparts were readily preyed upon [53,58]. Interestingly, the authors of this study posited that the production of the biofilm alone was not enough to dissuade predators or prevent predation but was more a combination of other secreted antiprotozoal factors. It seems possible that bacterial communities living within a biofilm, especially in lieu of quorum sensing $[59,60]$, may be capable of modulating a concerted effort towards the increased production of virulence effectors adversely affecting potential predators. Similarly, biofilms have been shown to protect ingested bacteria against the insect immune system [61]. Following successful initial evasion, it is possible that ingested (or in the case of this study-injected) bacteria may be able to cement themselves firmly inter- and/or intracellularly and begin the production of various virulence factors.

Whereas no differences in grazing rates by C. elegans and A. polyphaga were found in Pto::fleQ compared to the Pto wildtype; the opposite was found in the G. mellonella toxicity assay. Hypertoxicity of the fleQ mutant was thought to be attributed to an overproduction of the fleQ-regulated negatively-charged exopolysaccharide alginate (encoded by algD). This suggestion was supported by the creation of an $\operatorname{alg} D$ mutant, which was completely attenuated in its virulence capability in G. mellonella. Alginate is one of several known virulence factors produced by P. syringae which facilitate proliferation of infections upon colonization of plants [37]. Although there is some indication of the importance of $\operatorname{alg} D$ in virulence of $P$. aeruginosa in CF patients [35] there is very little evidence of its role in invertebrate infection. Indeed, a P. aeruginosa alg $D$ mutant was not impaired in virulence of either plants, nematodes or mice [62]. Conversely, a P. fluorescens NZ17 algU/mucA transposon mutant expressed reduced nematode repellency compared to its wild-type [15] and AlgU, an RNA polymerase sigma factor, is necessary for the expression of mucoidy and $a \lg D$ transcription [63]. As production of alginate is known to be highly associated with biofilm formation in P. syringae [64] it is possible that psl $A$ and $\operatorname{alg} D$ work cooperatively to cause hypervirulence in G. mellonella.

Both nGOT and aGOT assays revealed how the pilus forming associated gene, pilj, increased resistance to predation with a knockout Pto::pilJ mutant exhibiting lowered survivability in C. elegans and A. polyphaga. PilJ is a chemosensory protein which interacts directly with PilA-an important subunit in the overall pilin structure [65]. Pili are well known for their abilities to promote bacterial adhesion both to various biotic [66-68], and abiotic surfaces [69]. This adhesion is considered to be the initial step in the formation of a biofilm crucial to the survival and indeed virulence of many microorganisms in their respective hosts or environments [70]. In P. aeruginosa signal transduction regulating cAMP production and transcription of a large number of virulence genes followed contact of type IV pili with solid surfaces [65]. Whilst the role of pili in bacterial virulence in animal models is well characterized, in this study, interestingly, the pilj mutant was not attenuated in its ability to cause mortality in G. mellonella. On the other hand, pathogens including a Burkholderia pseudomallei 
pilA mutant had reduced adherence to human epithelial cells and was found to be less virulent in C. elegans [71].

Pili linked genes are known to be highly associated with the che gene cluster [72] and the pil-chp (che) pathway controls type IV pilus production and twitching motility in P. aeruginosa [73]. Both pil and che gene clusters have been shown to be essential in chemotaxis in P. aeruginosa [74] and in turn modulate flagella expression and activity. Via methyl-accepting chemotaxis proteins $\mathrm{CheW}$ sends a signal to the histidine protein kinase CheA which ultimately stimulates rotation of the flagella in P. syringae [75]. While the primary role of flagella is for locomotion they also serve as important chemosensory organelles, adhesins and virulence factors facilitating invasion into host tissue [76,77]. Due to difficulties in creating a cheW mutant a closely associated cheA mutant was created to act as a surrogate in survival and virulence trials. The Pto::cheA mutant exhibited lowered survivability in C. elegans and A. polyphaga but, interestingly, no effect on G. mellonella mortality was observed. In a similar study, the closely associated methyltransferase CheB2, required for mobility and chemotaxis in $P$. aeruginosa, was found to be critical in virulence of both C. elegans killing (70\% attenuation in CheB2 mutant) and murine lung infection [78]. Transposon mutants in cheA, cheB and cheR in two Salmonella enterica serovars, however, revealed that these genes were of minor importance in interactions with C. elegans [79]. In this same study, the authors observed reduced interactions of a fliC mutant attenuated in ability to produce flagellin, another key element in the construction of the overall flagella machinery, with amoebae. The conflicting observations reported in these studies illustrate a differential contribution of the chemotaxis systems in three pathogens. Potentially, as an enteric, Salmonella has evolved alternative mechanisms for survival in the nematode. It has also been reported that identically encoded virulence factors shared across bacterial taxa do not automatically result in pathogenicity associated at these loci $[80,81]$.

Increased survivability of E. coli to C. elegans and A. polyphaga was conferred by an Rhs (Rearrangement Hotspot) factor. Survival of Pto::rhsD was attenuated in subsequent competition trials with both predators. Virulence in G. mellonella was lowered (30\%) but this was not statistically significant. Whilst Rhs elements are widely distributed across bacterial genera little still is known about their overall function [41] although the structure of various $A B C$ toxin subunits are known to contain Rhs repeats [82] indicating that many Rhs proteins in the database are in fact toxins. Expression of $r h s D$ appears to contribute to virulence and we speculate that this may be due to a synergistic cooperation and combined activity of various virulence factors. This suggestion is corroborated in a recent study on the plant pathogen Xanthomonas oryzae where XadM, a cell surface protein in the Rhs family, was found to be important in several virulence mechanisms including attachment and biofilm formation [83]. Rhs elements have also been associated with the type VI secretion system (T6SS) and in Dickeya dadantii, RhsA is thought to be exported via this secretion complex. The target of this secreted protein has not been clearly elucidated but it is possibly an effector protein associated with virulence.

The final gene identified in our three-pathogen screening assay was hlyD. HlyD belongs to a family of membrane fusion proteins involved in the transportation of $\alpha$-haemolyin toxins via a type I secretion system which is common to and crucial in virulence of many Gram-negative pathogens [84]. Interestingly, E. coli hlyD shares highly comparable protease secretion functions with the important phytopathogen Dickeya dadantii (syn. Erwinia chrysanthemi, Pectobacterium chrysanthemi) $[85,86]$ which has been recognised as a potent experimental pathogen of the pea aphid Acyrthosiphon pisum [21]. Although we were not able to create a Pto::hlyD mutant we successfully created a mutation in a related haemolysin, hlyIII. Whilst survival of the mutant to C. elegans was initially observed after a 24-h period this was no longer the case at $72 \mathrm{~h}$. Remarkably, and mirroring the results recorded for Pto::fleQ, we found the hlyIII mutant was hypervirulent towards G. mellonella, an unexpected result. Even though there is little evidence in the literature of any direct role which HlyIII may play in virulence in vivo, a study in Bacillus cereus suggests that, dependent on temperature, HlyIII forms oligomeric transmembrane pores in human erythrocytes thereby lysing them [87]. 


\section{Conclusions}

In the current study we investigated the genetic mechanisms behind survival of $P$. syringae upon challenge by two invertebrate predators and toxicity towards an insect as an alternate host. Due to the ecological niche that it occupies, the likelihood that $P$. syringae encounters y these organisms is high. Armed with this knowledge we hypothesised that $P$. syringae has evolved specialist mechanisms to cope with such stressors. Although various pseudomonads are well characterized animal pathogens, with $P$. aeruginosa being the classically referenced strain known for its arsenal of potent virulence factors [88], P. syringae is generally referred to as a plant pathogen [89] with little or no pathogenicity towards animals. A recent study has provided evidence of the pathogenic potential of $P$. syringae MB03 towards the nematode $C$. elegans using a range of bioassays [80]. Further transcriptional assays conducted by these authors revealed a number of candidate virulence genes (namely alg $U$, algL, pilA, fliC and fleN) during the infection process [80] which were either detected, likewise, in our study and are described here or are intimately associated with them. Indeed, our GOT screening identified 358 cosmids that provided weak to strong survival or toxicity phenotypes. Notwithstanding cosmid overlap and that not all genes on the cosmids are relevant, it does illustrate that optimal bacterial survival/toxicity is polygenic and complex in nature.

To our knowledge this is the first time that a study, encompassing a host-pathogen interaction assay involving three different $P$. syringae strains in three unrelated invertebrate hosts, has been conducted. A similar study testing scale of pathogenicity of 12 different $P$. syringae isolates found close correlation between epiphytic ability and virulence towards insects [90]. Interestingly the Cit7 strain [90,91], considered nonpathogenic to plants, was the most virulent towards two well characterized hemipteran insect pests. Our results give further insight into the complex interactions occurring on the surface of plants between epiphytic and potentially entomopathogenic bacteria and plausible crop pests as well as support the possibility of using P. syringae as a biocontrol agent in non-host plants.

Supplementary Materials: The following are available online at http:/ /www.mdpi.com/2076-2607/6/2/32/s1, Table S1: List of primers used in this study, Table S2: Summary of best hits and identified gene regions from the RVA using $P$ to as a reference.

Acknowledgments: All work was funded by the University of Reading to which we are extremely grateful.

Author Contributions: F.D. and G.A.B. co-wrote the manuscript. F.D. conducted experimental work. R.W.J. and N.R.W. conceived the idea and contributed to experimental design. M.S.-C., T.A. and J.M. contributed to experimental work. All authors contributed to interpretation of results, contributed to discussions and approved the final draft.

Conflicts of Interest: The authors declare that the research was conducted in the absence of any commercial or financial relationships that could be construed as a potential conflict of interest.

\section{References}

1. Demba Diallo, M.; Monteil, C.L.; Vinatzer, B.A.; Clarke, C.R.; Glaux, C.; Guilbaud, C.; Desbiez, C.; Morris, C.E. Pseudomonas syringae naturally lacking the canonical type III secretion system are ubiquitous in nonagricultural habitats, are phylogenetically diverse and can be pathogenic. ISME J. 2012, 6, 1325-1335. [CrossRef] [PubMed]

2. Morris, C.E.; Monteil, C.L.; Berge, O. The life history of Pseudomonas syringae: Linking agriculture to earth system processes. Annu. Rev. Phytopathol. 2013, 51, 85-104. [CrossRef] [PubMed]

3. Morris, C.E.; Conen, F.; Alex Huffman, J.; Phillips, V.; Pöschl, U.; Sands, D.C. Bioprecipitation: A feedback cycle linking Earth history, ecosystem dynamics and land use through biological ice nucleators in the atmosphere. Glob. Chang. Biol. 2014, 20, 341-351. [CrossRef] [PubMed]

4. Monteil, C.L.; Bardin, M.; Morris, C.E. Features of air masses associated with the deposition of Pseudomonas syringae and Botrytis cinerea by rain and snowfall. ISME J. 2014, 8, 2290-2304. [CrossRef] [PubMed] 
5. Mansfield, J.; Genin, S.; Magori, S.; Citovsky, V.; Sriariyanum, M.; Ronald, P.; Dow, M.; Verdier, V.; Beer, S.V.; Machado, M.A.; et al. Top 10 plant pathogenic bacteria in molecular plant pathology. Mol. Plant Pathol. 2012, 13, 614-629. [CrossRef] [PubMed]

6. Morris, C.E.; Bardin, M.; Kinkel, L.L.; Moury, B.; Nicot, P.C.; Sands, D.C. Expanding the paradigms of plant pathogen life history and evolution of parasitic fitness beyond agricultural boundaries. PLoS Pathog. 2009, 5, e1000693. [CrossRef] [PubMed]

7. Amato, P.; Parazols, M.; Sancelme, M.; Laj, P.; Mailhot, G.; Delort, A. Microorganisms isolated from the water phase of tropospheric clouds at the Puy de Dôme: Major groups and growth abilities at low temperatures. FEMS Microbiol. Ecol. 2007, 59, 242-254. [CrossRef] [PubMed]

8. Morris, C.E.; Kinkel, L.L.; Xiao, K.; Prior, P.; Sands, D.C. Surprising niche for the plant pathogen Pseudomonas syringae. Infect. Genet. Evol. 2007, 7, 84-92. [CrossRef] [PubMed]

9. Lovell, H.C.; Mansfield, J.W.; Godfrey, S.A.; Jackson, R.W.; Hancock, J.T.; Arnold, D.L. Bacterial evolution by genomic island transfer occurs via DNA transformation in planta. Curr. Biol. 2009, 19, 1586-1590. [CrossRef] [PubMed]

10. Jackson, R.W.; Johnson, L.J.; Clarke, S.R.; Arnold, D.L. Bacterial pathogen evolution: Breaking news. Trends Genet. 2011, 27, 32-40. [CrossRef] [PubMed]

11. Arnold, D.L.; Lovell, H.C.; Jackson, R.W.; Mansfield, J.W. Pseudomonas syringae pv. phaseolicola: From "has bean" to supermodel. Mol. Plant Pathol. 2011, 12, 617-627.

12. Aminov, R.I. Horizontal gene exchange in environmental microbiota. Front. Microbiol. 2011, 2, 158. [CrossRef] [PubMed]

13. Tan, M.W.; Rahme, L.G.; Sternberg, J.A.; Tompkins, R.G.; Ausubel, F.M. Pseudomonas aeruginosa killing of Caenorhabditis elegans used to identify P. aeruginosa virulence factors. Proc. Natl. Acad. Sci. USA 1999, 96, 2408-2413. [CrossRef] [PubMed]

14. Ruiz-Díez, B.; Sánchez, P.; Baquero, F.; Martínez, J.L.; Navas, A. Differential interactions within the Caenorhabditis elegans-Pseudomonas aeruginosa pathogenesis model. J. Theor. Biol. 2003, 225, 469-476. [CrossRef]

15. Burlinson, P.; Studholme, D.; Cambray-Young, J.; Heavens, D.; Rathjen, J.; Hodgkin, J.; Preston, G.M. Pseudomonas fluorescens NZI7 repels grazing by C. elegans, a natural predator. ISME J. 2013, 7, 1126-1138. [CrossRef] [PubMed]

16. Axelsson-Olsson, D.; Waldenström, J.; Broman, T.; Olsen, B.; Holmberg, M. Protozoan Acanthamoeba polyphaga as a potential reservoir for Campylobacter jejuni. Appl. Environ. Microbiol. 2005, 71, 987-992. [CrossRef] [PubMed]

17. Gourabathini, P.; Brandl, M.T.; Redding, K.S.; Gunderson, J.H.; Berk, S.G. Interactions between food-borne pathogens and protozoa isolated from lettuce and spinach. Appl. Environ. Microbiol. 2008, 74, 2518-2525. [CrossRef] [PubMed]

18. Tezcan-Merdol, D.; Ljungström, M.; Winiecka-Krusnell, J.; Linder, E.; Engstrand, L.; Rhen, M. Uptake and replication of Salmonella enterica in Acanthamoeba rhysodes. Appl. Environ. Microbiol. 2004, 70, 3706-3714. [CrossRef] [PubMed]

19. Barret, M.; Egan, F.; Moynihan, J.; Morrissey, J.P.; Lesouhaitier, O.; O'Gara, F. Characterization of the SPI-1 and Rsp type three secretion systems in Pseudomonas fluorescens F113. Environ. Microbiol. Rep. 2013, 5, 377-386. [CrossRef] [PubMed]

20. Stavrinides, J.; McCloskey, J.K.; Ochman, H. Pea Aaphid as both host and vector for the phytopathogenic bacterium Pseudomonas syringae. Appl. Environ. Microbiol. 2009, 75, 2230-2235. [CrossRef] [PubMed]

21. Grenier, A.-M.; Duport, G.; Pagès, S.; Condemine, G.; Rahbé, Y. The phytopathogen Dickeya dadantii (Erwinia chrysanthemi 3937) is a pathogen of the pea aphid. Appl. Environ. Microbiol. 2006, 72, 1956-1965. [CrossRef] [PubMed]

22. Costechareyre, D.; Balmand, S.; Condemine, G.; Rahbé, Y. Dickeya dadantii, a plant pathogenic bacterium producing Cyt-like entomotoxins, causes septicemia in the pea aphid Acyrthosiphon pisum. PLoS ONE 2012, 7, e30702. [CrossRef] [PubMed]

23. Ratcliffe, N.A. Invertebrate immunity-A primer for the non-specialist. Immunol. Lett. 1985, 10, $253-270$. [CrossRef]

24. Hilker, R.; Munder, A.; Klockgether, J.; Losada, P.M.; Chouvarine, P.; Cramer, N.; Davenport, C.F.; Dethlefsen, S.; Fischer, S.; Peng, H.; et al. Interclonal gradient of virulence in the Pseudomonas aeruginosa pangenome from disease and environment. Environ. Microbiol. 2015, 17, 29-46. [CrossRef] [PubMed] 
25. Péchy-Tarr, M.; Bruck, D.J.; Maurhofer, M.; Fischer, E.; Vogne, C.; Henkels, M.D.; Donahue, K.M.; Grunder, J.; Loper, J.E.; Keel, C. Molecular analysis of a novel gene cluster encoding an insect toxin in plant-associated strains of Pseudomonas fluorescens. Environ. Microbiol. 2008, 10, 2368-2386. [CrossRef] [PubMed]

26. Waterfield, N.R.; Sanchez-Contreras, M.; Eleftherianos, I.; Dowling, A.; Yang, G.; Wilkinson, P.; Parkhill, J.; Thomson, N.; Reynolds, S.E.; Bode, H.B.; et al. Rapid virulence annotation (RVA): Identification of virulence factors using a bacterial genome library and multiple invertebrate hosts. Proc. Natl. Acad. Sci. USA 2008, 105, 15967-15972. [CrossRef] [PubMed]

27. King, E.O.; Ward, M.K.; Raney, D.E. Two simple media for the demonstration of pyocyanin and fluorescin. J. Lab. Clin. Med. 1954, 44, 301-307. [PubMed]

28. Sambrook, J.; Fritsch, E.F.; Maniatis, T. Molecular Cloning: A Laboratory Manual; Cold Spring Harbor Laboratory: Cold Spring Harbor, NY, USA, 1989.

29. Buell, C.R.; Joardar, V.; Lindeberg, M.; Selengut, J.; Paulsen, I.T.; Gwinn, M.L.; Dodson, R.J.; Deboy, R.T.; Durkin, A.S.; Kolonay, J.F.; et al. The complete genome sequence of the Arabidopsis and tomato pathogen Pseudomonas syringae pv. tomato DC3000. Proc. Natl. Acad. Sci. USA 2003, 100, 10181-10186. [CrossRef] [PubMed]

30. Green, S.; Studholme, D.J.; Laue, B.E.; Dorati, F.; Lovell, H.; Arnold, D.; Cottrell, J.E.; Bridgett, S.; Blaxter, M.; Huitema, E.; et al. Comparative genome analysis provides insights into the evolution and adaptation of Pseudomonas syringae pv. aesculi on Aesculus hippocastanum. PLoS ONE 2010, 5, e10224.

31. Joardar, V.; Lindeberg, M.; Jackson, R.W.; Selengut, J.; Dodson, R.; Brinkac, L.M.; Daugherty, S.C.; DeBoy, R.; Durkin, A.S.; Giglio, M.G.; et al. Whole-genome sequence analysis of Pseudomonas syringae pv. phaseolicola 1448A reveals divergence among pathovars in genes involved in virulence and transposition. J. Bacteriol. 2005, 187, 6488-6498. [PubMed]

32. Cooper, V.S.; Carlson, W.A.; LiPuma, J.J. Susceptibility of Caenorhabditis elegans to Burkholderia infection depends on prior diet and secreted bacterial attractants. PLoS ONE 2009, 4, e7961. [CrossRef] [PubMed]

33. Jackson, R.W.; Athanassopoulos, E.; Tsiamis, G.; Mansfield, J.W.; Sesma, A.; Arnold, D.L.; Gibbon, M.J.; Murillo, J.; Taylor, J.D.; Vivian, A. Identification of a pathogenicity island, which contains genes for virulence and avirulence, on a large native plasmid in the bean pathogen Pseudomonas syringae pathovar phaseolicola. Proc. Natl. Acad. Sci. USA 1999, 96, 10875-10880. [CrossRef] [PubMed]

34. Oza, J.P.; Yeh, J.B.; Reich, N.O. DNA methylation modulates Salmonella enterica serovar Typhimurium virulence in Caenorhabditis elegans. FEMS Microbiol. Lett. 2005, 245, 53-59. [CrossRef] [PubMed]

35. Tart, A.H.; Wolfgang, M.C.; Wozniak, D.J. The alternative sigma factor AlgT represses Pseudomonas aeruginosa flagellum biosynthesis by inhibiting expression of fleQ. J. Bacteriol. 2005, 187, 7955-7962. [CrossRef] [PubMed]

36. Zhao, S.; Sandt, C.H.; Feulner, G.; Vlazny, D.A.; Gray, J.A.; Hill, C.W. Rhs elements of Escherichia coli K-12: Complex composites of shared and unique components that have different evolutionary histories. J. Bacteriol. 1993, 175, 2799-2808. [CrossRef] [PubMed]

37. Keith, R.C.; Keith, L.M.W.; Hernández-Guzmán, G.; Uppalapati, S.R.; Bender, C.L. Alginate gene expression by Pseudomonas syringae pv. tomato DC3000 in host and non-host plants. Microbiology 2003, 149, 1127-1138. [PubMed]

38. McCaslin, C.A.; Petrusca, D.N.; Poirier, C.; Serban, K.A.; Anderson, G.G.; Petrache, I. Impact of alginate-producing Pseudomonas aeruginosa on alveolar macrophage apoptotic cell clearance. J. Cyst. Fibros. 2015, 14, 70-77. [CrossRef] [PubMed]

39. Lee, K.Y.; Mooney, D.J. Alginate: Properties and biomedical applications. Prog. Polym. Sci. 2012, 37, $106-126$. [CrossRef] [PubMed]

40. Guilhelmelli, F.; Vilela, N.; Albuquerque, P.; Derengowski, L.D.S.; Silva-Pereira, I.; Kyaw, C.M. Antibiotic development challenges: The various mechanisms of action of antimicrobial peptides and of bacterial resistance. Front. Microbiol. 2013, 4, 353. [CrossRef] [PubMed]

41. Koskiniemi, S.; Lamoureux, J.G.; Nikolakakis, K.C.; t’Kint de Roodenbeke, C.; Kaplan, M.D.; Low, D.A.; Hayes, C.S. Rhs proteins from diverse bacteria mediate intercellular competition. Proc. Natl. Acad. Sci. USA 2013, 110, 7032-7037. [CrossRef] [PubMed]

42. Kung, V.L.; Ozer, E.A.; Hauser, A.R. The accessory genome of Pseudomonas aeruginosa. Microbiol. Mol. Biol. Rev. 2010, 74, 621-641. [CrossRef] [PubMed] 
43. Sisto, A.; Cipriani, M.G.; Morea, M.; Lonigro, S.L.; Valerio, F.; Lavermicocca, P. An Rhs-like genetic element is involved in bacteriocin production by Pseudomonas savastanoi pv. savastanoi. Antonie Van Leeuwenhoek 2010, 98, 505-517. [CrossRef] [PubMed]

44. Croft, L.; Beatson, S.A.; Whitchurch, C.B.; Huang, B.; Blakeley, R.L.; Mattick, J.S. An interactive web-based Pseudomonas aeruginosa genome database: Discovery of new genes, pathways and structures. Microbiology 2000, 146 Pt 1, 2351-2364. [CrossRef] [PubMed]

45. Kung, V.L.; Khare, S.; Stehlik, C.; Bacon, E.M.; Hughes, A.J.; Hauser, A.R. An rhs gene of Pseudomonas aeruginosa encodes a virulence protein that activates the inflammasome. Proc. Natl. Acad. Sci. USA 2012, 109, 1275-1280. [CrossRef] [PubMed]

46. Platt, M.W. In vivo hemolytic activity of group B streptococcus is dependent on erythrocyte-bacteria contact and independent of a carrier molecule. Curr. Microbiol. 1995, 31, 5-9. [CrossRef] [PubMed]

47. Overhage, J.; Schemionek, M.; Webb, J.S.; Rehm, B.H.A. Expression of the psl operon in Pseudomonas aeruginosa PAO1 biofilms: PslA performs an essential function in biofilm formation. Appl. Environ. Microbiol. 2005, 71, 4407-4413. [CrossRef] [PubMed]

48. Zhang, J.; Holdorf, A.D.; Walhout, A.J. C. elegans and its bacterial diet as a model for systems-level understanding of host-microbiota interactions. Curr. Opin. Biotechnol. 2017, 46, 74-80. [CrossRef] [PubMed]

49. Donato, V.; Ayala, F.R.; Cogliati, S.; Bauman, C.; Costa, J.G.; Leñini, C.; Grau, R. Bacillus subtilis biofilm extends Caenorhabditis elegans longevity through downregulation of the insulin-like signalling pathway. Nat. Commun. 2017, 8, 14332. [CrossRef] [PubMed]

50. Shtonda, B.B.; Avery, L. Dietary choice behavior in Caenorhabditis elegans. J. Exp. Biol. 2006, 209, 89-102. [CrossRef] [PubMed]

51. Zhang, Y.; Lu, H.; Bargmann, C.I. Pathogenic bacteria induce aversive olfactory learning in Caenorhabditis elegans. Nature 2005, 438, 179-184. [CrossRef] [PubMed]

52. Hibbing, M.E.; Fuqua, C.; Parsek, M.R.; Peterson, S.B. Bacterial competition: Surviving and thriving in the microbial jungle. Nat. Rev. Microbiol. 2010, 8, 15-25. [CrossRef] [PubMed]

53. Matz, C.; Kjelleberg, S. Off the hook-How bacteria survive protozoan grazing. Trends Microbiol. 2005, 13, 302-307. [CrossRef] [PubMed]

54. Jousset, A.; Lara, E.; Wall, L.G.; Valverde, C. Secondary metabolites help biocontrol strain Pseudomonas fluorescens CHA0 to escape protozoan grazing. Appl. Environ. Microbiol. 2006, 72, 7083-7090. [CrossRef] [PubMed]

55. Chen, W.-J.; Hsieh, F.-C.; Hsu, F.-C.; Tasy, Y.-F.; Liu, J.-R.; Shih, M.-C. Characterization of an insecticidal toxin and pathogenicity of Pseudomonas taiwanensis against insects. PLoS Pathog. 2014, 10, e1004288. [CrossRef] [PubMed]

56. Murakami, K.; Ono, T.; Viducic, D.; Somiya, Y.; Kariyama, R.; Hori, K.; Amoh, T.; Hirota, K.; Kumon, H.; Parsek, M.R.; et al. Role of $p s l$ genes in antibiotic tolerance of adherent Pseudomonas aeruginosa. Antimicrob. Agents Chemother. 2017, 61, e02587-16. [CrossRef] [PubMed]

57. Darby, C.; Hsu, J.W.; Ghori, N.; Falkow, S. Plague bacteria biofilm blocks food intake. Nature 2002, 417, 243-244. [CrossRef] [PubMed]

58. Matz, C.; McDougald, D.; Moreno, A.M.; Yung, P.Y.; Yildiz, F.H.; Kjelleberg, S. Biofilm formation and -phenotypic variation enhance predation-driven persistence of Vibrio cholerae. Proc. Natl. Acad. Sci. USA 2005, 102, 16819-16824. [CrossRef] [PubMed]

59. Irie, Y.; Parsek, M.R. Quorum sensing and microbial biofilms. Curr. Top. Microbiol. Immunol. 2008, 322, 67-84. [PubMed]

60. Parsek, M.R.; Greenberg, E.P. Sociomicrobiology: The connections between quorum sensing and biofilms. Trends Microbiol. 2005, 13, 27-33. [CrossRef] [PubMed]

61. Vallet-Gely, I.; Lemaitre, B.; Boccard, F. Bacterial strategies to overcome insect defences. Nat. Rev. Microbiol. 2008, 6, 302-313. [CrossRef] [PubMed]

62. Yorgey, P.; Rahme, L.G.; Tan, M.-W.; Ausubel, F.M. The roles of mucD and alginate in the virulence of Pseudomonas aeruginosa in plants, nematodes and mice. Mol. Microbiol. 2008, 41, 1063-1076. [CrossRef]

63. Martin, D.W.; Holloway, B.W.; Deretic, V. Characterization of a locus determining the mucoid status of Pseudomonas aeruginosa: AlgU shows sequence similarities with a Bacillus sigma factor. J. Bacteriol. 1993, 175, 1153-1164. [CrossRef] [PubMed] 
64. Laue, H.; Schenk, A.; Li, H.; Lambertsen, L.; Neu, T.R.; Molin, S.; Ullrich, M.S. Contribution of alginate and levan production to biofilm formation by Pseudomonas syringae. Microbiology 2006, 152, 2909-2918. [CrossRef] [PubMed]

65. Persat, A.; Inclan, Y.F.; Engel, J.N.; Stone, H.A.; Gitai, Z. Type IV pili mechanochemically regulate virulence factors in Pseudomonas aeruginosa. Proc. Natl. Acad. Sci. USA 2015, 112, 7563-7568. [CrossRef] [PubMed]

66. Taguchi, F.; Ichinose, Y. Role of type IV pili in virulence of Pseudomonas syringae pv. tabaci 6605: Correlation of motility, multidrug resistance, and HR-inducing activity on a nonhost plant. Mol. Plant-Microbe Interact. 2011, 24, 1001-1011. [CrossRef] [PubMed]

67. Pizarro-Cerdá, J.; Cossart, P. Bacterial adhesion and entry into host cells. Cell 2006, 124, 715-727. [CrossRef] [PubMed]

68. Kline, K.A.; Fälker, S.; Dahlberg, S.; Normark, S.; Henriques-Normark, B. Bacterial adhesins in host-microbe interactions. Cell Host Microbe 2009, 5, 580-592. [CrossRef] [PubMed]

69. Berne, C.; Ducret, A.; Hardy, G.G.; Brun, Y.V. Adhesins involved in attachment to abiotic surfaces by Gram-negative bacteria. Microbiol. Spectr. 2015, 3. [CrossRef] [PubMed]

70. Pohlschroder, M.; Esquivel, R.N. Archaeal type IV pili and their involvement in biofilm formation. Front. Microbiol. 2015, 6, 190. [CrossRef] [PubMed]

71. Essex-Lopresti, A.E.; Boddey, J.A.; Thomas, R.; Smith, M.P.; Hartley, M.G.; Atkins, T.; Brown, N.F.; Tsang, C.H.; Peak, I.R.A.; Hill, J.; et al. A type IV pilin, PilA, contributes to adherence of Burkholderia pseudomallei and virulence in vivo. Infect. Immun. 2005, 73, 1260-1264. [CrossRef] [PubMed]

72. Bardy, S.L.; Maddock, J.R. Polar localization of a soluble methyl-accepting protein of Pseudomonas aeruginosa. J. Bacteriol. 2005, 187, 7840-7844. [CrossRef] [PubMed]

73. Whitchurch, C.B.; Leech, A.J.; Young, M.D.; Kennedy, D.; Sargent, J.L.; Bertrand, J.J.; Semmler, A.B.T.; Mellick, A.S.; Martin, P.R.; Alm, R.A.; et al. Characterization of a complex chemosensory signal transduction system which controls twitching motility in Pseudomonas aeruginosa. Mol. Microbiol. 2004, 52, 873-893. [CrossRef] [PubMed]

74. Kelly-Wintenberg, K.; Montie, T.C. Chemotaxis to oligopeptides by Pseudomonas aeruginosa. Appl. Environ. Microbiol. 1994, 60, 363-367. [PubMed]

75. Manoharan, B.; Neale, H.C.; Hancock, J.T.; Jackson, R.W.; Arnold, D.L. The identification of genes important in Pseudomonas syringae pv. phaseolicola plant colonisation using in vitro screening of transposon libraries. PLOS ONE 2015, 10, e0137355.

76. Haiko, J.; Westerlund-Wikström, B. The role of the bacterial flagellum in adhesion and virulence. Biology 2013, 2, 1242-1267. [CrossRef] [PubMed]

77. Moens, S.; Vanderleyden, J. Functions of bacterial flagella. Crit. Rev. Microbiol. 1996, 22, 67-100. [CrossRef] [PubMed]

78. Garvis, S.; Munder, A.; Ball, G.; de Bentzmann, S.; Wiehlmann, L.; Ewbank, J.J.; Tümmler, B.; Filloux, A. Caenorhabditis elegans Semi-Automated Liquid Screen Reveals a Specialized Role for the Chemotaxis Gene cheB2 in Pseudomonas aeruginosa Virulence. PLoS Pathog. 2009, 5, e1000540. [CrossRef] [PubMed]

79. Olsen, J.E.; Hoegh-Andersen, K.H.; Casadesús, J.; Thomsen, L.E. The importance of motility and chemotaxis for extra-animal survival of Salmonella enterica serovar Typhimurium and Dublin. J. Appl. Microbiol. 2012, 113, 560-568. [CrossRef] [PubMed]

80. Ali, M.; Sun, Y.; Xie, L.; Yu, H.; Bashir, A.; Li, L. The pathogenicity of Pseudomonas syringae MB03 against Caenorhabditis elegans and the transcriptional response of nematicidal genes upon different nutritional conditions. Front. Microbiol. 2016, 7, 805. [CrossRef] [PubMed]

81. Lee, D.G.; Urbach, J.M.; Wu, G.; Liberati, N.T.; Feinbaum, R.L.; Miyata, S.; Diggins, L.T.; He, J.; Saucier, M.; Deziel, E.; et al. Genomic analysis reveals that Pseudomonas aeruginosa virulence is combinatorial. Genome Biol. 2006, 7, R90. [CrossRef] [PubMed]

82. Busby, J.N.; Panjikar, S.; Landsberg, M.J.; Hurst, M.R.H.; Lott, J.S. The BC component of ABC toxins is an RHS-repeat-containing protein encapsulation device. Nature 2013, 501, 547-550. [CrossRef] [PubMed]

83. Pradhan, B.B.; Ranjan, M.; Chatterjee, S. XadM, a Novel Adhesin of Xanthomonas oryzae pv. oryzae, Exhibits Similarity to Rhs Family Proteins and Is Required for Optimum Attachment, Biofilm Formation, and Virulence. Mol. Plant-Microbe Interact. 2012, 25, 1157-1170. [PubMed] 
84. Kim, J.-S.; Song, S.; Lee, M.; Lee, S.; Lee, K.; Ha, N.-C. Crystal structure of a soluble fragment of the membrane fusion protein HlyD in a type I secretion system of Gram-negative bacteria. Structure 2016, 24, 477-485. [CrossRef] [PubMed]

85. Guzzo, J.; Duong, F.; Wandersman, C.; Murgier, M.; Lazdunski, A. The secretion genes of Pseudomonas aeruginosa alkaline protease are functionally related to those of Erwinia chrysanthemi proteases and Escherichia coli a-haemolysin. Mol. Microbiol. 1991, 5, 447-453. [CrossRef] [PubMed]

86. Létoffé, S.; Delepelaire, P.; Wandersman, C. Protease secretion by Erwinia chrysanthemi: The specific secretion functions are analogous to those of Escherichia coli alpha-haemolysin. EMBO J. 1990, 9, 1375-1382. [PubMed]

87. Baida, G.E.; Kuzmin, N.P. Mechanism of action of hemolysin III from Bacillus cereus. Biochim. Biophys. Acta 1996, 1284, 122-124. [CrossRef]

88. Gellatly, S.L.; Hancock, R.E.W. Pseudomonas aeruginosa: New insights into pathogenesis and host defenses. Pathog. Dis. 2013, 67, 159-173. [CrossRef] [PubMed]

89. Xin, X.-F.; He, S.Y. Pseudomonas syringae pv. tomato DC3000: A model pathogen for probing disease susceptibility and hormone signaling in plants. Annu. Rev. Phytopathol. 2013, 51, 473-498. [PubMed]

90. Smee, M.R.; Baltrus, D.A.; Hendry, T.A. Entomopathogenicity to two hemipteran insects is common but variable across epiphytic Pseudomonas syringae strains. Front. Plant Sci. 2017, 8, 2149. [CrossRef] [PubMed]

91. Hirano, S.S.; Upper, C.D. Population biology and epidemiology of Pseudomonas syringae. Annu. Rev. Phytopathol. 1990, 28, 155-177. [CrossRef]

(C) 2018 by the authors. Licensee MDPI, Basel, Switzerland. This article is an open access article distributed under the terms and conditions of the Creative Commons Attribution (CC BY) license (http://creativecommons.org/licenses/by/4.0/). 